情報管理 Vol. 32 No. $10 \quad$ Jan. 1990

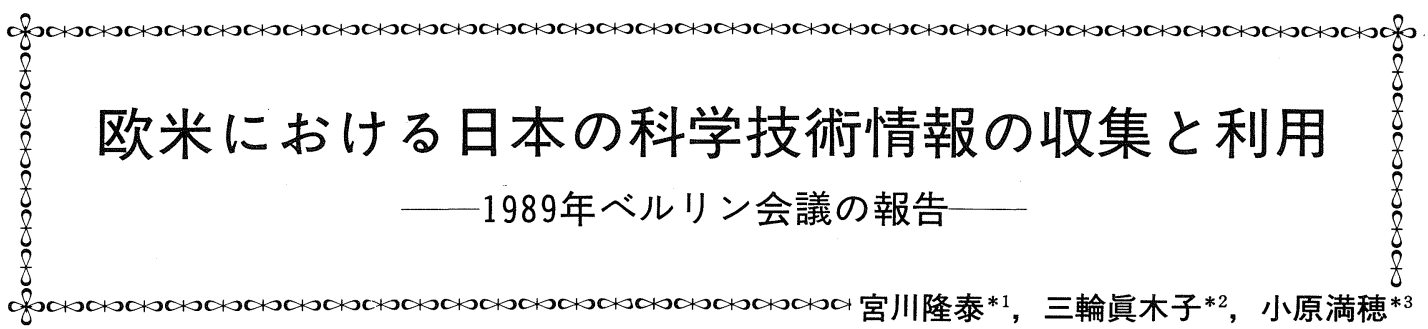

\title{
Collection and utilization of Japanese scientific and technological information in Europe and U.S.A. Report on the Berlin Conference 1989
}



[著者抄録］ 1989 年 10 月 23〜25 日の間, ベルリン日独センターで,「第 2 回科学技術と商業 に関する日本情報国際会議」が開催された。1987 年 9 月英国ウオーリックで第 1 回会議が開か れて以来 2 年間に, 欧米各国における日本科学技術・産業情報の収集・利用・評価には一層の 進展がみられた。一方日本政府関係情報サービス機関, 民間データベース事業者の対外提供体 制も次第に整備され，有益な意見交換が行われた。会議は全体で 11 セッションに分かれ，全体 的傾向と各国の政策, 各国の情報資源, 利用と分析, 漢字処理と機械翻訳, 日本との直接コン タクトなどのテーマについて発表と討論が行われた。

[著者付与キーワード］＼cjkstart科学技術情報，データベース，情報政策，機械翻訳，JICST，GMD

[Author Abstract] The 2nd International Conference on Japanese Information in Science Technology and Commerce was held on October 23-25, 1989 at Japanisch-Deutsches Zentrum Berlin, Federal Republic of Germany. During two years since previous Conference at Warwick, England, in 1987, much progresses were made in collecting, using and evaluating Japanese scientific, technological and inudstrial information in Western countries. On the other hands, overseas supply of Japanese databases and information by Japanese governmental and private organizations have been improved in many aspects. There occurred presentation of papers and valuable exchange of opinions and experiences. The Conference consisted of II Sessions which covered trends and policies, various information sources, analysis and distributions, Japanese language and Kanji processings and direct connection with Japan.

[Keywords by Author] scientific and technological information, database, information policy, machine translation, JICST, GMD

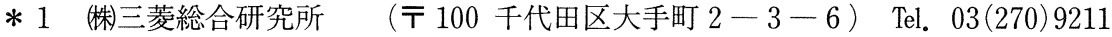

Mitsubishi Research Institute, Inc. $\quad(3-6$, Otemachi 2 -chome, Chiyoda-ku, Tokyo 100)

*2 侏エポックリサーチ（テ 164 中野区中野 2-7-12-106） Tel。03(382) 1384

Epoch Research Corporation $\quad(7-12-106$, Nakano 2-chome, Nakano-ku, Tokyo 164)

*3 日本科学技術情報センター, 企画室（广 100 千代田区永田町 2-5 - 2 ） Tel。 03 (581)6411 JICST, Planning Office $\quad(5-2$, Nagatacho 2 -chome, Chiyoda-ku, Tokyo 100) 


\section{1. 会 議 の 概 要}

1989 年 10 月 23 日〜25日の 3 日間にわたり,西 ドイツのベルリンにあるベルリン日独センター で,「第 2 回科学技術および商業に関する日本情報 の国際会議（The 2 nd International Conference on Japanese Information in Science, Technology and Commerce)」が開催された。第 1 回目の この会議は, 1987 年 9 月に英国のウオーリック大 学で，英国図書館 Japanese Information Service とウオーリック大学 Japanese Business Policy Unitの主催で行われた。今回の第 2 回目の会議 は, 西ドイツ研究技術省付属情報処理研究所 (Gesellschaft für Mathematik und Datenverarbeitung : GMD), ベルリン日独センター(Japanisch Deutsches Zentrum Berlin)，およびベルリ ン州立図書館 (Staatsbibliothek Preussischer Kulturbesitz)の共催で開催され，欧米の日本情報 関係者と日本からの参加者の合計 150 名が， 3 日 間にわたって情報交換と討論を繰り広げた (1-1)。

会議の主旨は，科学技術および産業分野におい て日本で発生している様々な情報を，欧米でどの ように収集し利用するかというものである。登録 参加者は, 西ドイツ 46 名, 英国 15 名, フランス 5 名, 北欧三国 10 名, その他を加之, ヨーロッパ 各国から 88 名, 米国 21 名, 日本 41 名, 合計 150 名で，その所属は政府機関，情報サービス機関， 図書館, 大学, コンサルタント, 大企業の情報部 門などであった。

会議では全部で招待講演を含む 42 論文が $10 セ$ ッションで発表された。うち日本からの発表は 14 件であった（プログラムの詳細と各論文の内容に ついては，本稿末尾の参照文献を参照されたい)

(1-2)。

また，前回と同様に会場に隣接して展示会場が 開設され，全部で 29 機関・企業が出展し，資料の 展示や情報サービスシステムのデモンストレーシ ヨンを実施した。日本からは, JICST, NACSIS, 平和情報センター，エレクトリック・ライブラリ 一，帝国データバンク，日本電子計算がデモンス
トレーションを実施したほか，データベース振興 センター，日本データベース協会，情報科学技術 協会，東京ブレーン・トラストなどが展示ブース を出展した。また国会図書館 Japan MARCのJ/ BISCも，GMDブースで実演された。

\section{2. 欧米の 政 策}

1987 年に英国ウオーリック大学で開催された 第 1 回会議以降，欧米では日本科学技術・産業情 報の収集・利用を強化する政策が引き続きとられ ている。まず米国では 1987 年から施行された $\lceil$ Japan Technical Literature Act（日本技術文献 法)」の下で，米国商務省の Japan Technical Literature Office（日本技術文献局）では，米国 における日本の技術情報の収集・モニタリング活 動を調整するために様々な活動を展開している が，割り当てられた予算は決して大きな額ではな く，法案を可決した米国議会は，その後の成り行 きにあまり関心を示していないようである。ただ し，日本技術文献局の活動は，同じ商務省下にあ る NTISの日本文献の Acquisition Program と うまく調整されており，入手された日本技術文献 の英訳の米国内での売れ行きはよいと言う。この ことは，既存の流通経路の中に，なじみやすい形 で日本情報をとり入れていくやり方が，米国で受 け容れられていることを示している。

この JTLAに加え，1987〜88 年にかけて米政 府側でいくつか新しい政策的動きがみられた。第 1 は 1988 年 6 月に調印された日米科学技術研究 開発協力協定 (Agreement between the Government of the United States of America and the Government of Japan on Cooperation in Research and Development in Science and Technology)である。これは 1980 年に締結された 協定の改訂であったが，実質的には情報利用のた めの相応な機会 (comparable access) や知的所有 権の考え方が持ち込まれ新協定となった。

全米科学振興財団 (NSF) は過去 30 年にわたっ て日本との間で科学者・技術者交換プログラムを 
実施してきたが，1988 年にあたらしく「Japan Initiative」を開始し，日本の大学や官民の研究所 に研究者や語学研修生を送りこみ，6か月以上の 研修を受けさせている。1988 年には 30 人がこの 計画により日本に派遣された。日本側も文部省・ 科学技術庁が同様のプログラムを実施（文部省・ 科学技術庁合計で, 年間 200 人の受入れ予定), 効 果を上げている $(2-1)$ 。

さらに全米科学・工学アカデミー (National Academy of Science and Engineering) でも 1988 年 3 月に日本室（Office of Japan Affairs）を設 置し，日本科学技術情報利用に関して，再国の学 界の間の協力関係を改善・強化するための活動を 開始した $(2-2)$ 。

今回の会議では，ウオーリック会議ではみられ なかった民間の大企業における日本情報収集・利 用に関する報告が，AT\&Tの Bell 研究所と，ゼ ロックス社の Palo-Alto Research Center から なされた。この報告では，大企業が日本情報を専 門に扱う「テクニカル・ゲートキーパ」を抱え， 既存の情報源だけでなく，日本の支社や関連会社 との人脈を通じた最新情報の収集に力を入れてい る点が印象的であった。

一方，NSF からの委託で実施されている「日本 技術評価プログラム (Japanese Technology Evaluation Program (JTECH)」等のプロジェク 卜を通じて，日本を訪問する米国の研究者・技術 者が増加しており，ここでも人的交流を通じた直 接的な情報入手の空口を拡大するための努力がな されている。また，日本で実施されている ERATO プロジェクトでは，外国人の研究者を招 聘しており，最近では高度な研究を行う研究者も 日本に行くことに積極的になってきている。ペン シルバニア州のコンサルタント, International Science and Technology Associates では，日本 へ行く研究者を斡旋しており，米国だけでなく欧 州からも広く人材を集めようとしている(2-3)。

米国内での日本の灰色文献に対する関心の高ま りは，1988 年と 1989 年に訪日調査を実施してい ることでも明らかであるが，それらの調査の成果
は，従来は一律に「灰色文献」とみなされていた ものの中にも，「灰色の濃度には様々な違いがあ る」ことがわかってきたことである $(2-4)$ 。次の ステップは，どの「灰色文献」に焦点を当てて収 集活動をどのように展開するかであるが，この点 については明確な方針はまだ示されていない。

ヨーロッパ側からは，ウオーリック会議の主催 者で，今回の会議の開催にも尽力した英国図書館 の Japan Information Service が，出来る限りの 日本情報を提供するという目標を掲げて，基本参 考図書とオンラインデータベースを備えて，利用 者にサービスを提供している現状が紹介された $(2$ - 5 )。月間 90 件にのぼる問い合わせの大部分は電 話によるもので，55\%が企業情報， $14 \%$ \%゙統計情 報, $12 \%$ が業界団体に関するものである。ヨーロ ッパ内の日本の科学技術・ビジネス情報サービス 担当部門では, EUROJIN (European Association of Japanese Information Agencies) というイン フォーマルな人的ネットワークを構成して，相互 に協力し合ってサービスを行っている。また，英 国内ではロンドン周辺地域の日本に関連した経 済・ビジネス情報提供機関同士の人的交流が芽生 えている。

第 1 回目の会議で大々的に報告された，EC 委 員会第 13 総局多国語政策部 (Multilingnal Action Programme, GD-13, EEC) の予算による Japan-Info Project は，その後の経過報告がほと んどなされなかったため，ヨーロッパ側の動きの 詳細は不明であるが，データベース化の仕組みは 一応できあがっており，今後は日本側から提供す る情報の質と，民間ベースでのヨーロッパ内での 流通が課題となる $(2-6)$ 。

\section{3. 日本の対外提供}

日本側の情報サービス機関による諸外国への科 学技術およびビジネス情報の提供については，デ ータベース・サービス機関を中心に全部で 6 件の 報告がなされた。論文を提出したが会議では発表 されなかったものを含めると, 全部で 8 件もあり, 
日本側サービスの積極的な対外展開の姿勢がうか がわれた。

\section{1 JICST の情報提供努力}

(1)英文データベースの作成・提供

海外諸国からの日本で発生する科学技術情報提 供の強い要求に答えるため, JICST は日本におけ る科学技術情報の中枢的機関として, STN International および JOIS を通じて英文データベース (JICST-Eファイル)の提供を行い, 科学技術情報 の国際的流通の促進を図ってきた。

さらに, JICST がこの JICST-Eファイルを研 究者, 学協会, 大学, 出版会社等々との連携・協 力の下に, 年々拡大・充実させている。このJICST$\mathrm{E}$ ファイルは, 1988 年に日本で発生した文献の約 $81.5 \%$ をガーしており，日本情報へのアクセス として有用なツールである。

また, 研究者の努力により, 英文論文の数は年及 増大し, 1988 年では約 24,000 件に達し, JICST$\mathrm{E}$ ファイルでは約 $12 \%$ 割合を占めており, 特に基 礎科学分野が高い率を示している。

論文に対する英文標題および英文抄録の付与に ついても, 研究者, 学協会, 大学, 出版会社等の 努力により年々増加しており, 英文抄録は 1988 年 ではJICST-Eファイルの全記事の約 $31.5 \% に$ 付与されている $(3-1)$ 。

さらに一層の国際的流通の促進を図るため, JICST 公共資料ファイルを英文化し，1989 年か ら JICST-Eファイルにマージしてサービスを開 始した。また, JICST 科学技術研究情報の英文版 をサービスすべく，ローディング用プログラムを 開発中である。

(2)灰色文献の流通

「日米科学技術研究開発協力協定」のなかでも見 られるように，欧米諸国の灰色文献に対する二ー ズは極めて高い。JICST はこれに対しても積極的 に答えてきた。一般に灰色文献と称される技術レ ポート, 委託研究報告書, 会議録, 予稿集等を積 極的に収集し, JICST-Eファイルに収録してき た。これらの記事の割合はJICST-Eファイルの
全記事の約 $40 \%$ を占めている。さらに, 次年度か らは以下の構想をもっている(3-2)。

(1)英文アクセス情報の作成

以下の 3 種類の所在情報を作成する。

・試験研究機関情報空口一覧

・日本の科学技術情報提供機関台帳

・日本のファクトデータベース台帳

(2)日本の科学技術情報の普及説明

欧米諸国で，日本情報のコンサルテーション 活動，オンラインデータベースおよび機械翻 訳システムのデモンストレーションを行う。

\section{2 公的機関のサービス展開}

学術情報センターは, 米国の NSF との間に専 用回線を開設して，同センターで開発した日本情 報のデータベースの対外提供を積極的に進めてい る。新たに提供を開始したデータベースとしては， 日本の学協会が主催する全国大会, 研究会等にお ける研究発表の概要をデータベースにした,「学会 発表データベース」および日本の化学関連学会刊 行の論文雑誌に掲載される学術論文の全文を収録 し，図表，写真類もファクシミリで提供する「化 学全文データベース」である。これらを加えると， 同センターから米国に提供されている日本情報の データベースは, 全部で 8 種類にのぼっている。 今後は英国図書館をはじめ欧米の他機関との間に も専用回線を開設してNSF と同様のサービスを 提供すると共に，提供するデータベースの種類を 増加していく予定である(3-3)。

国立国会図書館は，日本の出版物（一般図書・ 雑誌のほか, 官公庁出版物, 博士論文, 会議論文 や会議録などのかなり多岐にわたる灰色文献を含 む）を包括的に収集し，国内外の利用者に閲覧， 複写, 間接貸出, レファレンス等のサービスを通 じて提供している。収集した出版物の目録情報は, Japan-MARC として機械可読化され, MT と CD -ROM (J-BISC) として外部にも提供されている。 海外へのサービスに関しては，年間約 4 千件の郵 送等による文献複写の依頼に対応しており, IFLA の図書資料国際利用プログラムを通じて海 
外の図書館にも貸出しを行っている。また，海外 からの参考調查依頼にも対応している。1996 年を 目途に，関西地域に第二国立図書館を開設する計 画が進められており，これが実現すれば，日本の 書誌情報センターとして, 内外の利用者に複写や 貸出しのサービスを提供できるようになる予定で ある $(3-4) 。$

\section{3 データベース・サービスの国際化}

日本国内での国産データベースサービスについ ては, 通商産業省から発行されている『データべ 一ス台帳総覧』によれば，その数は 1982 年には 122 種であったものが，1988 年には 528 種に増加 しており，日本で利用できる全データベース $(1964$ 種)中の国産データベースの比率は $26.9 \%$ で，相 変わらず対外依存度が高いとはいうものの, 日本 国内でのデータベースを通じた日本情報へのアク セスはかなり改善されてきている。特に，1986 年 以来，ファクトデータベースの数がリファレンス データベースの数を超えており，この傾向は年々 顕著になっている $(3-5)$ 。

日本のデータベースサービスの対外提供に関し ては，日本データベース協会が実施した 3 回にわ たる「日本のデータベース・サービスの国際化に 関する実態調査」の結果が報告された。これによ ると, 1987 年には海外から利用できる日本製デー タベースは 28 種のみであったが， 2 年後の 1989 年には 104 種となっており，この 2 年間で日本の データベースサービスが急速に国際化しているこ とが明らかとなった。しかしながら，日本のデー タベース産業にとって，サービスの国際化は，(1) 相手国でのサービス拠点や代理店の設置，(2)英訳 の品質とコスト，(3)国際通信網の品質の不統一, (4)海外利用者のニーズ把握が困難, (5)海外ベンダ との契約，といった様々な問題点を内包している ことも提示され，日本の情報を英文化してデー夕 ベースとして海外に提供していくことは容易なこ とではないことも明らかとなった。日本のデー夕 ベースを全て英文化するのは不可能であるから， 英文化は収益性のある分野（企業，証券，経済な
ど）にとどめ，その他の分野については日本語で 灰色文献を含むあらゆる出版物の書誌データベー スを構築し，海外で日本語のわかるサーチャを育 成する方が効果的であるとの提案も成された。そ の際，日本の特定の情報を入手したい外国人に， どこに問い合わせればよいか，どのデータべース を利用すればよいかなどの，クリアリング情報を 提供する空口の存在の重要性も指摘された (3-6)。

なお,民間のデータベースサービスに関しては, 平和情報センターの HINET と COM-NET を通 じた，ビジネスデータベースの海外提供の事例が 詳しく紹介された。日本の新聞記事情報の中には， 一般紙に掲載される一般情報と，業界紙や産業新 聞に掲載される特定産業に関連した専門情報の 2 種類があることが指摘された。また，日本の新聞 社は大抵 CTS システムを導入しており，全文デ ータベースを提供する用意が出来ていることも紹 介された (3-7)。

日本では，データベースプロデューサがディス トリビュータを兼ねている事例がこれまでは多く みられたが，最近ではプロデューサ専業者も増加 しており，ゲートウェイサービスの登場に伴い， 利用者のデータベースへのアクセスが以前よりは 容易になってきているとの指摘もなされた。

帝国データバンクと(認) 総合研究開発機構 (NIRA)は，各々のサービスを紹介する論文を提 出したが，会議での発表は行なわれなかった。た だしペーパーは予稿集に掲載されている。また， 日本の特許情報を利用している欧米の利用者か ら, JAPIOのデータベースに関する多くの論文が 発表されたにもかかわらず，肝心の JAPIOから の参加者が一人もなかったのは，残念というより もむしろ奇異な感じを，内外の参加者に与えた。

\section{4. 欧米の情報源}

\section{1 米大学のユニオンリスト}

欧米各国にはすでにかなりの量の日本情報が, 大部分印刷物の形で，主として図書館に所蔵され ている。ここでの問題は，アクセスが難しいこと 
ではなく，これらをいかに有効に活用するかとい うことである。

米国各地の大学図書館のうち約 20 館でそれぞ れ相当量の日本文献を所蔵しているが，最近の情 勢により収集方針の相互調整と所蔵する参考書誌 類や逐次刊行物の所在情報の集中が必要になって きた。このため米連邦政府機関である日米友好委 員会 (Japan-United States Friendship Commission)からの助成により，全米を東海岸，中西部抒 よび西部の 3 地域に分け，各地の大学図書館が所 蔵している日本逐次刊行物の総合目録が編集され た (4-1)。これらにより日本語文献によるユーザに 対するリファレンス支援が容易になることが期待 されている。

\section{2 西独の日本情報源}

今回の会議では西独における日本文献収集・利 用状況が明らかにされた (4-2)。西ドイツには日本 情報を収集し提供する中央図書館はないが，以下 の七つの図書館が分野別に日本文献を収集してお ク，これに対するアクセスは全独逐次刊行物デー タバンク (Zeitschriftendatenbanken)を通して可 能であり，かつ図書館間相互貸出制度が動いてい る。これらの制度は連邦政府と州政府共同で設 立・運営している財団であるドイツ研究協会 (Deutsche Forschungsgemeinschaft)により,財政的に 支持されている。七つの機関とは,

ハノーバー技術情報図書館，（Technische Informationsbibliothek, Hannover) 科学技術全般

医学中央図書館 (Zentralbibliothek der Medizin, Köln)

経済学中央図書館 (Zentralbibliothek der Wirtschaftswissenschaften, Kiel)

農業中央図書館 (Zentralbibliothek der Landbauwissenschaften, Bonn)

プロイセン文化財団ベルリン州立図書館 (Staatsbibliothek Preussischer Kulturbesitz, Berlin）人文・社会科学，政府刊行物。 バイエルン州立図書館（Bayerische Staatsbibliothek, München) 人文科学，稀観書。
アジア研究所 (Institut für Asienkunde, Hamburg）社会科学分野の灰色文献。

これらの 7 図書館で所蔵する日本逐次刊行物は 約 6,000 夕イトルで，これにより図書館相互貸出 制度を通って入ってくる要求の $80 \%$ を処理して いる。ドイツ国内で処理できないものは, GMD 東 京事務所へ転送している。またこれと並んで IFLA (国際図書館連盟)の国際図書館相互貸出制 度を経由して寄せられる要求も処理している。こ の場合はとくに東欧諸国からの資料請求が多い。 また 1987 年から FIZ/Karlsruhe で STN が稼 働したことにより,ハノーバーの TIB とケルン医 学図書館の所蔵文献についてはオンラインによる 複写依頼ができるようになった。

西ドイツの日本コレクションの当面する問題点 は，日本語が読める情報専門家がきわめて少ない こと，および全独（もしくは欧州全域をカバーし た）日本コレクションのユニオンカタログが未だ 出来ていないことである。中国文献については数 年前に全欧中国逐次刊行物ユニオンリス卜 (EASL-EDOCS) が上述の全独逐次刊行物データ バンクに基づいて構築されているが，日本文献に はまだこの種のものはない。今回のベルリン会議 直後に結成されたヨーロッパ日本学図書館員協会 (European Association of Japanese Resource Specialists）の今後の活動が期待される。

ベルリン州立図書館ではこのほかにドイツ語で 刊行された日本語文献の書誌目録データベースを 構築中である。この作業は 1980 年より開始され, 1985 年までにまず 6 巻本として印刷されたが, 現 在順次コンピュータに入力中である。すでに完成 したのはその第 1 部で，1477 年から 1920 年まで の単行書, 雑誌, 地図である。このなかにはマル コポーロの東方見聞録の独訳初版本も含まれてい る。現在の計画では 1996 年までの間に, 55,000 件 の書誌目録をデータベース化し，ついで CD／ ROM にも入力するとのことである。このプログ ラムは JAIL Media と呼ばれている(4-3)。 


\section{5. 特許と画像}

\section{1 特 許 情 報}

特許は出願した者が法的独占権を得ることを目 的として技術内容を公表するが，その者の技術水 準が的確に表現されていることから，技術情報と

して重要な価值を有している。

日本での特許・実用新案の出願から登録までは 以下の手続きが踏まれる。

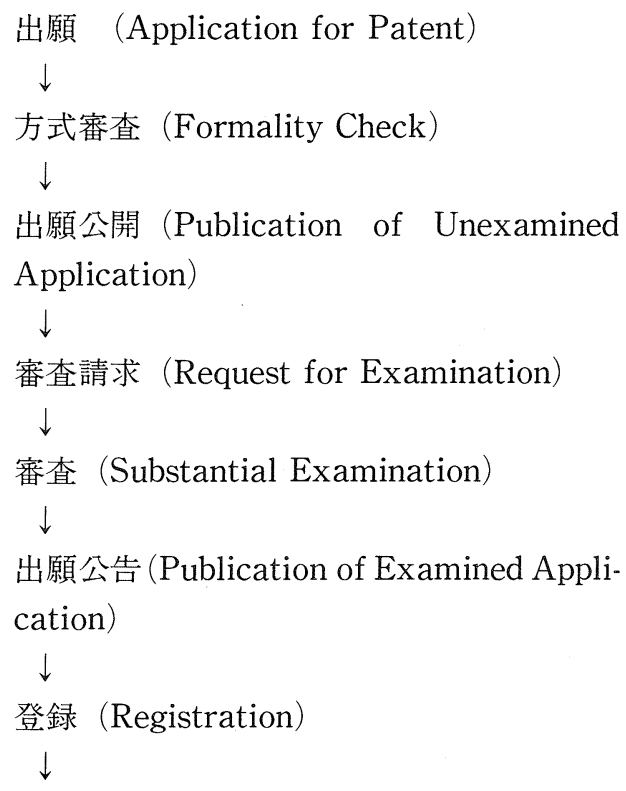

出願公告 (Publication of Examined Application)

$\downarrow$

登録（Registration）

$\downarrow$

特許権の終了 (Termination of Patent Right)

このような流れを経る過程で出願，出願公開， 出願公告，登録のそれぞれの段階において独自の 番号が付与されており，このことが混乱を招く一 つの要因となっている。また, 特許・実用新案の 内容が公開されるのは, 出願公開 (公開特許公報, 公開実用新案公報）と出願公告（特許公報，実用 新案公報）である。

日本の特許制度の特質という理由もあるが，特 許の出願数, 公開特許数, 公告特許数は世界一で あり，世界での特許数のなかでも大きな割合を占 め, 実用新案を含めるとさらにその割合は増える。 また，各主要国に対する日本からの出願特許件
数も大きな割合を占め, 例えば 1987 年では, 米国 において $19 \%$ ，ヨーロッパ特許では $15.9 \%$ ，西 独では $10.9 \%$ ，英国では $15.3 \%$ と当該国に次ぐ 比率を占めている $(5-1,5-2)$ 。顕著な例としては, 米国特許分類 Class 300 (磁気記録)では, ソニー, 日立, 富士写真フィルムが上位を占めていること が挙げられる (5-3)。

近年の先端分野における日本の技術力の向上に つれて，海外から日本特許情報に対するニーズが 強まり，英文情報はもちろんのこと日本文情報に 対してもアクセスの努力が見られる。英文による 特許情報のサービスは以下の三つがある (5-1，52)。

(1) Patent Abstract of Japan (PAJ)

JAPIO が整備する英文データベースで日本の 公開特許公報が収録されている。また JAPIO は 特許, 実用新案, 商標㧍よびその法的段階の調查 サービスも行っている。PAJのオンラインサービ スは Pergamon Orbit Infolineにより JAPIOフ アイルとしてサービスされている。

(2) World Patent Index (WPI)

Derwentにより作成されているデータベース で, 日本特許については上記 PAJ より収録は少な く 4,800 件/週である。ただし抄録あるいはミニ 抄録はすべての記事に付与されている。このデー タベースはDialog, Pergamon Orbitおよび Telesystem-Questelにより利用できる。また WPI は複写・翻訳サービスも行っている。

(3) International Patent Documentation (INPADOC)

比較的多くの日本特許情報が収録されている が，抄録は付与されていない。しかし，法的段階 情報は収録されている。1973 年 4 月以降の日本特 許情報はすべて網羅している。

日本の特許情報について以下のようないくつか の問題点・課題が指摘された $(5-1,5-2,5-3)$ 。

・PATOLIS と WPI では収録に差がありすぎ る。

- PATOLISの出願人の表記が統一されてい ないこともあり，不正確なことがある。 
・日本語タイトルが意味不明なものがあり, 請 求範囲を適切に表していないことがある。

・ヨーロッパでは漢字端末の入手が困難であ ク，大手できたとしても非常に高価である。 ・将来の課題はグラフィックとフルテキスト化 である。

\section{2 画 像 情 報}

最近の CD-ROM，光ディスクファイリングシ ステムそして高品質ファクシミリの進歩により， 画像 (イメージ) データベースが注目されている。 日本における画像情報サービスは予想以上に多い $(5-4)$ 。

\section{(1) NEEDS-IS}

日本経済新聞社の画像データベース。フルテキ ストデータベース NEEDS-IR と組み合わせて利 用できる。新聞記事の画像をデジタル形態で別フ アイルに収録し，ユーザの申込によりファックス で画像を伝送している。申込は簡単でパソコン端 末のシングルコマンドで可能。料金は 1 枚 120 円。

(2) ELNET

侏エレクロニックライブラリの画像サービスで 三種類あり 32 の新聞，238の雑誌から 60 万件／ 年の記事について，テキスト，図，グラフを画像 として光ディスクに収録し，文字情報データベー スをオンライン検索用に掲載している。端末から のファックス送付要求があれば，記事の画像がフ アックスで送信される。料金は月 10 万円。

\section{(3) MAINET}

毎日新聞社が作成している 1868 年から現在ま での 120 万件の新聞写真データベース。400 500 件/日のデータが光ディスクに収録されている。才 ンラインでのサービスは行っていないので，利用 する場合は毎日新聞社への申し込みとなる。

(4)フォトディスクライブラリシステム

日本写真研究センター (JPRC) が作成している データベースで，日本の著名な写真専門家の約 5 万件のカラー写真を収録している。オンラインサ 一ビスは行っていないため, 代理店の端末，電話， ファックスでの申込みとなる。

\section{(5) JAPIO}

JAPIO が提供している CD-ROM による特許 のサービスで, 1987 年からサービスされている。 特許・実用新案の全文，図，写真を収録しており， レーザープリンタで出力される。検索はキーワー ドとコードで行い, 出力もシングルコマンドで可 能である。価格は 1 セット 350 万円。

\section{(6) ARCHI-FILE}

(侏建設情報センターが作成している土木・建築 に関するカラー写真・図面のデータベース。 3.5 万 件収録している。同センターのサービスであった CORNET は，新設の (財) 日本建設情報総合セン ターのサービスに吸収された。分類コードにより メニュー方式で検索される。光ディスクは 5 万 9 千円で販売されている。

今後の技術動向は：(1) G 4 ファックス，(2)パソ コンと連動した CD-ROM, (3)光ディスク。また課 題は：(1)オンラインアクセスの可能性，(2)検索技 法の改良, (3)画像と出力の改良。

\section{6. 日本情報の需要と供給}

\section{1 失 敗 の 事 例}

ウオーリック会議からベルリン会議までの 2 年 間に，米国では日本情報サービスが何種類も開始 されたが，同時にこの間三つのプログラムが中止 に追い込まれた。当初米側の日本情報サービス関 係者の間では，日本に関連する情報に対して潜在 需要はあるが,供給が不充分だと考えられていた。 しかし現実はそうではなくサービスを中断したも のもあり，また開始されたが利用者がまだ少なく 経営に苦しんでいるプログラムもある。これはな ぜであろうか $(6-1) 。$

中止されたプログラムの第 1 は, UMI 社 (University Microfilm International) の JTIS (Japanese Technical Information Service) であ った。プログラム責任者によると，失敗の原因は サービスの硬直性にあった。このサービスは英訳 抄録の月極女購読かもしくはDIALOGのオンラ イン検索に限られていた。この形のサービスは図 
書館向きではあったが「特注情報サービス（tailored information service)」を望むユーザには魅力 はなかった。その後ワシントン DCに設立された CIBER 社がこのサービスを引き継ぎ 1989 年秋 から新しい活動を開始する。同社の資金の $50 \%$ は 日本の富士ゼロックス社出資によるものである。

中止された第 2 のプログラムは, George Mason 大学 (バージニア州) の JTIRS (Japanese Technical Information Research Service) で, 日本技術情報についてのレファレンスサービスで あるが，これは主として米国大企業を対象に販売 活動を行なったが利用者の関心を集められなかっ た。失敗の原因はマーケティング活動が非効率で 不適切だったとされている。

第 3 のプログラムは米国電子工業会 (American Electronics Association) のニューズレタ 一・サービス「日本電子工業技術発展 (Technological Developments in Electronics in Japan)」で, 発売に際して 2 か月間に 17,000 通のダイレクト メールを流したが, 購読申込みはわずか 21 件にす ぎず，このプログラムは中止となった。

\section{2 成 功 $の$ 事 例}

このように利用者不足から失敗したプログラム がある反面，着実に成功しつつあるものもある。 その第 1 は米国商務省技術情報サービス局 (NTIS) の日本技術文献収集プログラムである。 この計画は 1982 年から開始されたものであるが, NTIS の日本総代理店である三菱総合研究所に情 報収集担当者を置き, 政府研究機関・民間企業研 究開発部門の研究報告や技報を収集しNTIS デ ータベース (GRA\&I) に入力しているものであ る。日本側からは年間平均 2,000 件の文献が送付 されているが, 現在 NTIS との間でとりきめを交 して文献送付に協力している機関は, 工業技術院 金下の国立研究所 15 機関, 科学技術庁傘下の 3 国 立研究所および民間企業 19 社(日立, 東芝, 日本 電気, 三菱電機, トヨ夕, 日産, 新日鉄, 三菱重 工業など）にのぼっている(6-2)。

米側の報告によればこれまで 1 文献につき平均
3 件の複写要求があるとのことであり，NTIS は 売れ行きは好調 (high) とみなしている。その理由 の一つは，利用者は日本文献であることを意識せ ずに注文できるからではないか，との指摘もあっ た。なおこのプログラムでは, 日本側では入手し た研究報告や技報をまったく加工せず，そのまま 米側に送付しているが，ほとんどの場合基本書誌 事項と抄録は日英併記となっている。本文は日本 語のままのことが多いが，米側はデータベースに その旨明示している。

成功している第 2 のプログラムは個別の日本技 術評価を内容とする JTECH である。当初このプ ログラムは商務省が支援し, SAIC (Science Application International Corporation) が実施 していたが, 現在ではNSFと国防省 DARPA (Defense Advanced Research Project Agency) が資金援助している。1987 年には 4 件 (先端電子 計算機, 軍事用半導体, セラミックスと半導体, Electro-Optics and Millimeter Wave)，1988 年 には 6 件（商業用高温超伝導，半導体工業への $\mathrm{CIM}$ と CAD の応用など), 1989 年には前半で 1 件 (Advanced Sensor) の日本技術の評価が行わ れている。この JTECH リポートはNTIS のベス トセラーに顔を出しており, また学会や専門誌で も紹介されている。

出版物としては同じくNTIS が『在米日本技術 情報源（Directory of Japanese Technical Resources in US)』という便覧を出しているが, その 1987 年版は 1,200 部売れたと報告された。ま た商務省日本技術文献局 (OJTL) のニューズレタ — “Japanese Technical Literature Bulletin”は 1988 年 9 月発行以降読者は漸増しており, 最近号 は 2,000 部を配布しているという。

\section{3 市場の特性と利用者の選択}

米側の説明によると NTIS データベースに入 力されている日本情報にたいする需要はまだ大き なものではない。この需要は大企業と小企業とに 2 極分化しており，中規模企業のニーズはこれに 比べると弱い。市場の 2 極分化に対応して必要と 
されている科学技術情報の種類も異なっている。 大企業・組織は詳細な技術報告 ( R \& D 成果) を要 求するが，一方小企業(ただしハイテク産業関連) ではレビュー型の文献，たとえばニューズレター や技術雑誌を要求している。ここでいう小企業と は従業員 50 人以下の企業であり, その経営者や管 理者がユーザとなっている。大企業にとっての問 題は，情報量がむしろ多すぎて，なにが適切なも のか評価するのが難しいことである。この場合, 日本の提携先，派遣人員など直接の日本とのつな がりが重要な意味をもつ。多くの米国大企業では, 日本との「情報危機」は存在せず, 必要な情報に 適切にアクセスできる状況にある(6-3)。

日本の先端技術情報にたいする需要調査（対象 分野は advanced ceramics）では企業や研究機関 の情報源は在来型技術文献だけではない。(専門 誌，業界誌，専門抄録サービス，特許情報など), このほかに以下のようなものがある $(6-4) 。$

・データベース検索。

・日本に専門家を派遣し, 会議に参加し研究所 を訪問する。

・米国の大学や政府の R\&D 計画への参加。

・国際的ブローカを雇い技術動向を追う。

- 日本企業の brochure, 技術資料, 社内報を入 手。

・日本企業と密接な実務的関係をつくる。

また英訳された日本文献について次のような興 味ある評価が示されている。ユーザが最もよく利 用するのは「技術論文の英文抄録」であり，つい で「日本の新聞記事の英訳」と「日本の研究機関 が出す研究報告の定期的要約」である。一方関心 の低いものは，「論文タイトルと著者名のみの翻 訳」，「全文翻訳」，「特許速報 (patent alert)」で ある。要するに日本の動向を早く, 落ちがなく観 察できて，しかも自分の目で選択できる形の情報 サービスがよく利用されている。日本側が予め選 定 (screening) したもの, あるいは米側仲介サ一ビ 又業者が選んで英訳したものは，収録範囲や信頼 性の点で問題がある。
STN の担当者の意見をヒアリングした結果が紹 介されたが，これによると，JICST-Eの知名度は まだ低い。また “no printing or downloading” という利用制限の影響については，他のデータべ 一スでも同様の利用制限のついているものもあ り，これがどの程度利用状況に影響しているかは 不明である $(6-1)$ 。

一方 NTIS が代理店になっている JICST-K の米国内での利用者は 30 機関であるが, うち 5 機 関は常時これを利用している $(6-5)$ 。JICST $/ \mathrm{E}$ お よび/Kの場合ともこのサービスの存在を, 多く の潜在的ユーザにまず知らせるための広報活動が つよく求められている。

\section{7. 米国における利用例}

\section{1 AT \& T の場合}

米国大企業の日本情報担当者より利用例の報告 があったのも今回の会議の特徵の一つである。ア メリカ電信電話会社 $(\mathrm{AT} \& \mathrm{~T})$ ベル研究所の情報 部では日本情報担当専任者が，社内各部門の多様 な要求を処理している。その報告によれば大企業 内利用者はそれ自体で多くの小市場と異分野を形 成していて，ニーズはすべて異なっている。ユー ザには研究部門の研究者，設計技術者，分析技術 者や管理部門の経営者, 特許弁理士などがあり, それぞれが必要とする日本情報の種類・形態・頻 度・媒体も異なっている。日本情報担当者は彼等 のニーズに応じて, 特別な主題についての最新二 ユース，重要な商品の情報，産業とマクロ経済に ついてのデー夕と分析，関連する政治情報や金融 データなどを，“best product”として提供しなけ ればならない。社内に提供する情報の種類として は速報 (alerting products)（日経，コムライン， JICST, 共同通信国際ニュースなどを利用)，二ュ ーズレター, journal contents bulletin, 定型的検 索サービス(SDI 式のもの)，レファレンス，原報 供給と翻訳などがある $(7-1)$ 。

JICSTの米国でのサービスについてはCAS／ 


\section{2 ゼロックス社の場合}

ゼロックス社パロアルト研究所はコンピュータ 関連機器の研究開発に特化しているが，その日本 情報担当者は, 最近日本側で提供しているデータ ベースや速報サービスは，数が多いばかりか高価 でしかも遅いといっている。日本についての情報, 日本からの情報の外国での流通方式は, 文化・言 語・地理的位置などのため複雑である。これに対 処するためゼロックス社では「歩道橋方式（footbridge solution)」をとっている。これは，学会情 報収集，出版物や灰色文献入手などについて，さ まざまな形での日本機関・企業との間に直接的な つながりをつけ，これによって文化と制度の壁を 乗り越えようとするものである。実例として学協 会の事例があげられているが，米国ではアメリカ 化学会 (ACS) の “Chemical and Engineering News”は15万部の購読者をもっているし， “IEEE Spectrum”は全世界で 30 万部配布されて いる。一方日本では重要で夕イムリ一な技術成果 は，学協会主催の会合で話されており，大規模な 国際会議においてではなく，日本語使用のローカ ルな会議で新しい成果が明らかにされることが多 い。ゼロックス社はこのような動向をフォローす るための情報ゲートキーパのネットワークを作り あげている $(7-2) 。$

このように多くの米国大企業は何等かの形で日 本国内に直接の関係先あるいは専門的技術ス夕ッ フをすでに配置している。彼等の任務は大略つぎ のようなものである。

・日本の学界との共同研究。

・日本市場のニーズをより正確に評価する。

・新製品のプロトタイプの評価。

・今後の競争の発生を判断し, これらの挑戦に 的確に対処する。

・会議やセミナーに参加し, 最新技術や革新に 関するアイデアや基本構想につき意見交換を 行う。通常これらの会議・セミナーは広く宣 伝されていない。

・企業や業界に対する新たな課題に受身でなく 積極的に対応する (7-3)。
ここで述べられていることは技術情報の収集に とどまらず，日本の新技術の評価とそれへの対応 策の検討である。技術情報の収集は, 当然のこと ながらそれ自体は一個の手段にすぎず，最終の目 的は技術の移転または新技術への対応策の確立な のである。この意味では，一部の米国大企業の例 からも伺えるように，大企業にとっては日本情報 のアクセス難や入手困難という問題はもはやなく なっているとみてよい。しかし日本に駐在員を派 遣することのできない業界や小企業や図書館や地 方のユーザなどにとっては，依然として日本情報 へのアクセスの困難が壁として残っているのであ る。

\section{8. 機 械 翻 訳}

前回のウオーリック会議でも指摘されたことで あるが，日本情報の国際的流通および利用におい て最大のネックは言語障壁であるという認識は樑 く浸透し，その解決手段としての機械翻訳に対す る期待はかなり大きく，今回は機械翻訳に関する 発表が 2 件あり，またこれに関連して言語解析， 漢字頻度分析, 他言語への変換技術についての発 表もあり，言語障壁解消への努力がみられた。な お, 隣接の展示会場でも機械翻訳は, JICSTを含 む 2 社が出展しており，多くの人々がデモンスト レーションを見学していた。

\section{1 機械翻訳システム展望}

1987 年に科学技術庁が作成した『日本の技術 1987-2015』(1987 年 9 月発行)では, 機械翻訳に ついて以下の如く予測している。

・1990 年代末までに，ある分野の英日機械翻訳 が広く普及する。

・ 2000 年までに実用的小型翻訳機が出現。

・2005 年までに携帯用通訳機が商品化。

現状を見れば，日英・英日機械翻訳システムは いくつか商用化されているが，多くの制約条件が あり，完全な自動翻訳への道はかなり遠いという のが実状であろう。ヨーロッパの日英機械翻訳の 
ユーザは次のようなジレンマをもっている。

・機械翻訳が実用化されるのはいつか。

・現状の機械翻訳システムの能力が十分と認識 する機関はあるのか。

・現在のシステムの画期的改善はいつか。

・新しいパラダイムによる研究は多くの投資を 必要とするのではないか $(8-1)$ 。

このように問題は多いが，日本においては機械 翻訳システムは積極的に推進されており，1987 年 9 月の箱根での「The Machine Translation Summit Conference」では，日本では 800 900 人の研 究者が機械翻訳の開発に従事し, 研究開発費用は 約 200 億円と発表された。また 1989 年 4 月に大磯 で開催された「International Forum for Translation Technology」では研究・開発を行なっている メーカおよび研究機関の多くが参加し，9社が商 用機械翻訳システムのデモンストレーションを行 つた。

これらのデモンストレーションで示された大き な流れは，大型計算機による翻訳システムからワ ークステーションによる翻訳システムへの移行で あろう。つまり，日立 2050 用システム，日本電気 EWS 4800 用システム, シャープDUETE/J シ ステム, 東芝 $\operatorname{AS} 3260$ 用システム, 三菱電機 MELCOM PSI II 用システム, 沖電気 if 1000 UTOPIA 用システム, リコーおよびサンヨー SWP 7800 用システムがそれである。

しかしながら，これらのシステムはハードウ工 アと密接に結びついており，ヨーロッパでの普及 には問題との認識を持たれている。

ただ一つ，ブラビスの Micropack J / E IIIのみ がハードウエアに拘束されないシステムとして特 徵づけられている。

今後の課題として次のことが指摘される。

・機械翻訳システムはすべての文章を完全に翻 訳できるシステムではなく, 設計仕様範囲で 動くエンジニアリングシステムであることを 認識する。

・したがって，エデットといった人間の手を介 することにより，実際に利用できる翻訳とな
る。

・すべての分野を対象とするのではなく，特定 主題の範囲内で行うべきである。

・各システムの辞書のなかの語数は 3 万〜 9 万 であり，拡充が不可欠である。

・より高度な機能を発揮させうるコンピュータ ソフトウエアの開発が必要である。

\section{2 JICST における機械翻訳システム}

実用規模の機械翻訳システムを開発している JICST からは, システムの経緯, 概要, スケジュ 一ル, 開発状況, 将来計画について詳しい説明が された。

JICSTの機械翻訳システムは1982年から 1985 年までに行われた科学技術振興調整費によ る「日英科学技術文献の速報システムに関する研 究」をもとにしている。この研究は, 京都大学, 電子総合研究所, JICST, 工業技術院, 科学技術 庁の 5 機関の共同研究として推進され，その成果 は良好で, 翻訳された文章の $80 \%$ は受容可能であ った。

JICST のシステムは以下の処理フローとなる。

(1)原文の入力：磁気媒体あるいは端末入力

(2)プレエデット：システムが理解できる文章 に修正

(3)翻訳： 形態素解析 $\rightarrow$ 構文解析 $\rightarrow$ 日英変換 $\rightarrow$ 構文生成 $\rightarrow$ 形態素生成

(4)ポストエデット：翻訳文のチェック

(5)文章出力

このシステムは 1989 年度から JICST-Eファ イルの抄録作成および翻訳サービスに試験的に利 用し，システム性能を評価する計画である。その 後 1990 年度から本格的運用に入る予定である。現 在の開発状況は，約 3,000の文法規則をもち，翻 訳辞書は約 30 万語で，100 抄録を評価中であり， 1989 年にはさらに多くの抄録を評価する段階に ある $(8-2)$ 。

今後の課題は以下の通りである。

・システムの改良：辞書, 文法規則

・日本語の問題：翻訳し易い日本語 
・最適な運用体制：文章作成者, プレエディタ, ポストエディタ，システム専門家の協力

- OCR：入力の迅速化

\section{3 文 章 解 析}

日本語は，(1)漢字，Uらがな，カタカナさらに ローマ字といった多くの文字種がある，(2)語の間 にブランクがないので，形態素解析が困難，(3)語 の並びの拘束が小さい，といった特徵により，英 語に比較して文章解析の面で困難さを持つ。しか し文章解析は, 機械翻訳, 自動索引, 自然語によ るデータベース検索の基礎的研究分野である。

今回は，日本語を構文解析したときのあいまい さの除去方法, ある漢字文字が特定の科学技術分 野に出現する頻度調査といった興味ある研究成果 が報告された $(8-3,8-4)$ 。

\section{9. 文化の違いと情報流通}

\section{1 文化の違いと日本型情報作法}

科学技術情報の対外提供について日本側の公的 情報サービスや民間データベースサービスが近年 多大の努力を払い，新しいサービスをつぎつぎに 始めていることについては，欧米の参加者は今回 の会議ではそれを評価する空気が強かった。それ にもかかわらず欧米の利用者の間には依然として 不満が広がっていることを指摘する専門家があっ た。すなわち「日本政府や民間研究所での研究は, 西欧人の目にも，また日本人自身から見てもよく 見えないことがある，と日本人自身がいっている。 実態は情報にたいするニーズと習慣が両者で異な っているからである」(9-1)。情報文化, 情報作法 がちがうという指摘である。

この文化的要素が状況を複雑にしている，と彼 等はいう。米国は個人的・企業家的行為者の国で あり, カウボーイ的精神構造を持ち, 情報は力で あると信じ，情報を保蔵 (hoard) してしまう。こ こで使われている hoarding とは財貨をためこん で使わない行為に対して用いられる経済学用語で ある。一方日本人は共同努力により生き残る式の
精神構造を持ち，情報を共有する者は力を持って いる，あるいは少なくとも影響力を持っていると 信じている。欧米人はここから複雑微妙な日本式 情報収集システムが形成されているとみているよ うだ。別の論者は日本での経営者・学者のインタ ビュー調査の結果を引用している(9-2)。

「日本の個別企業では, すべての従業員が, 外 部の公式の情報チャンネルを通して情報（ここ では intelligenceになっている）を集め流通さ せる。つぎに非公式で cross-organizational な コンタクトが通常は個人的レベルで行われる。 このなかには各部門内での集団討議も含まれて いる。第 3 には大企業内部での自然発生的な情 報流通には，終身雇用制度が影響を及ぼしてい る」

さらに個別企業の外側では, 産業グループ, 系 列 (keiretsu), 出身大学の学閥 (gaku-batsu) あ るいは先輩・後輩などのコンタクトネットワーク の上を情報が流れる。このような「終身雇用型情 報ネットワーク(lifetime network of information)」は重要な企業間ネットワークになってい る。系列グループ内の情報流通はより自由で正確 に行われるが，これは直接に競争する企業ではな いからである。競争企業の壁を超えて流れる情報 は, 通産省の産業振興策によって奨励されている ジョイントプロジェクトによることが多い。

\section{2 文化の違いをどうのりこえるか}

このような欧米専門家による日本企業内での情 報流通の描写が，はたして正確であるかどうかは ここで論ずる問題ではない。恐らくこれは情報流 通方式の比較分析という新しい課題である。情報 を作り出し，これを収集し利用する方式（情報作 法）には，それに関係する人々の思考，習慣，制 度など文化的要素が大きな影響を及ぼしている。 したがって, 日本と欧米との間でこの情報作法が 違っているのは当然のことである。しかし，その 相違を前提にした上で，なお情報流通は可能であ ると何人もが指摘していた。最も有効な方法は日 本に専門家を派遣し, 日本の情報作法に従って情 
報を大手することである。

すべての日本情報の潜在的ユーザがこのような 経費のかかる方式をとれるわけではない。しかし 少なくとも日本に直接の足場を持っている米国や 西独の大企業にとっては,「日本社会の織糸のなか に自らを織りこむことによって」その要求を十分 に満たしているとの報告があった。

「たとえば, 日本の学協会会員は情報共有セッ ションを頻繁に開く古くからの伝統がある。

この共有 (sharing) は通常口頭で行われる。会 議録は作成されず，参加者にのみ技術資料が配 布される。さらに会合の公式の通知はなく個人 的つながりを通して招待が流される。在日米企 業の代表者は，これらの重要できわめて夕イム リーな情報共有行為の参加者になったとき，つ いに日本のチームメンバーになれたと思うので ある」(9-3)。

西独シーメンス社研究開発部門の東京駐在員 は， 1983 年 1 月から 85 年 9 月までの 2 年 8 か月 の間, 70 人のシーメンス社員に 414 の日本企業と 研究所を訪問させ， 125 人の日本人科学者をシー メンスに紹介したと述べている。個人的なつなが りは，単なる会議での関係を補完する上でますま す重要になっており, 会社の研究能力の具体的な 延長とみなされるべきものであるだけでない。そ れは個人にとっての重要なモチベーションになる ものから，会社全体の国際競争力を支援するもの までさまざまな形のものがある(9-4)。

今回の会議では, 文化的背景や情報作法が違う から日本は異質であって協調できない，というよ うな，一部の政治家などの間にみられる短絡的な 日本批判は出なかった。むしろこれらの相違をど のように橋渡しできるかという議論が行われた。

アメリカ式のやり方は日本には通用しないのでは ないかという反省もみられた。例之ば；

「おそらく米国の最大の䛊りは日本からの情 報の収集, 流通, 分析を, 自分たちがよく知っ ており，また他の分野でうまくいった型に無理 に押し込もうとしていることにあるのではない か。恐らくわれわれのアプローチは，伝統的な
西洋のスプーンで日本ソバを食べようとするの に似ているといえるのではないか」(9-5)。

同じような議論が日本側からも出たのは興味深 かった。すなわち情報という材料を消化し易いよ うに料理する必要がある，アメリカの寿司はアメ リカ人の嗜好に合うように米風化されている。日 本情報をアメリカ風に料理してユーザのニーズに 合わせることが大事だという(9-6)。米側は日本風 になじめといい, 日本側は米風に調理せよという。 この辺りに双方の情報専門家が橋渡し役をつとめ ることができる重要な領域がありそうである。

\section{0. 今後の課 題}

1987 年のウオーリックと今回のベルリンの 2 回の会議を通じて，日本側の政府関係機関・民間 企業の対外情報提供サービスについての，欧米側 情報サービス関係者の認識は大いに深まったし， また欧米側の当面している問題点についての日本 側関係者の理解も梁くなった。この意味でこの 2

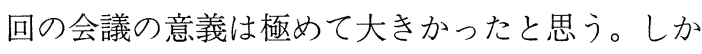
し日本情報の収集・利用・評価という課題は, 欧 米側にとってはまだようやく 10 年にも満たない 経験しかなく，今後解決を要する問題が山積して いる。以下に基本的な点を簡単に記しておきたい。

第 1 は，情報の収集・利用は，それ自体が目的 ではなく一手段にしかすぎないことである。最終 目的は米国企業の競争力の強化, 研究開発の推進, 「日本の挑戦(Japanese challenge)」にたいする対 応なのである。この点では米側の何人もの人が, 米大企業の戦略が最近では余りにも短期的目標に 支配されすぎていて，日本情報プログラムや科学 者の日本への関心・対応力を高めるための長期的 展望にたった投資を妨げていると指摘していた。 さらに最近の米企業の企業乗取りや売却などが, 安定性を好む日本人に不安を与えているとする米 側報告者もあった。この意味で，米側で日本情報 にたいする「意識喚起活動 (consciousness raising activities)」が一層必要だとする意見が出ていた し，もっとユーザを増やすことが，日本人に対す 
る米国側の責任だとの指摘もあった。

第 2 は日本の「情報文化 (information culture)」を理解する必要があるという，これも米側 からの指摘である。そのためのフォーラムを開き， 米国のデータベース業者・図書館員・研究者が日 本情報文化を理解するために，日本の専門家の助 力を得て討論してはどうかとの提案もあった。

第 3 は，欧米における日本情報の市場はどんな 構造になっているか，もっと詳しく調べる必要が ある。過去 2 回の会議でかなりわかってきたこと の一つは, 大企業やトップレベルの研究者は, 直 接日本に様々な形の足場や関係先を持っており， 日本情報へのアクセスにはあまり困難を感じてい ないらしいということである。当初大企業を対象 にしたアメリカの日本情報サービスが，近年いく つも失敗したのも，これが一因であった。とする とどのようなエンドューザが，どのような日本情 報を求めているのか，もっと正確につかむ必要が ある。今回の会議ではユーザの声が十分きかれな かったとする声があったが，会議自体をもっと広 範な聴衆に呼びかけてはどうかとの意見も欧米側 から出ていた。

第 4 は，日本情報サービスが別々に沢山ありす ぎること (proliferation)に対する困惑の声がきか れたことである。日本側としてはそれぞれ独自の サービス体制を作り上げたいとの希望が強いが, 他方欧米のユーザからみると，自分たちがなじん でいる情報サービスの中に日本のサービスも入っ てきてほしいという。日本側の対外提供サービス
体制の今後の在り方を，根本的に検討すべき時期 にきていると思う。

第 5 は，灰色文献は今回も多くの人が言及した が，その定義，その有用性，その質的評価につい てはほとんど討議されなかった。民間部門におけ る灰色文献 (industrial grey literature) について は今後問題になると思うが，今回はあまり意見は 出なかった。

第 6 は，言語障壁克服の方法として機械翻訳に 対する期待は大きく，いくつかの報告が行われ， それに関連した言語解析や漢字出現頻度分析など の研究も進められている。ただ機械翻訳の現実的 評価についてはまだ時期尚早であるようだ。

第 7 は，前回は出たが今回は出なかった問題と して日本語教育があった。欧米における日本語教 育の経験交流は，大事な問題であるが殆んど議論 されなかった。

第 8 は，関心は高かったのにまったくぺーパー が出なかったのが，日本特許情報と EC / Japan Info Projectであった。両方とも当事者から現状 の報告があって然るべきであったのにそれがなか ったのは，参会者に奇異の感を与えた。

最終日のパネル討論の際，フランスの代表の 1 人から，次回はフランスで開催することを検討し たいとの発言があった。次回がどのような形式と 内容の会議になるかはまだわからないが，それ迄 の間に，上にのべた多くの課題が少しでも解決の 方向に向かっていることを期待したい。

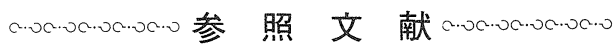

（1-1）なお今回の会議は西独側だけでなく,以下 の 4 か国，8機関が後援した。西独研究技術省 (BMFT), ベルリン市，カールスルー工専門情 報センタ一, 英国図書館, 米国商務省 NTIS, 日 本科学技術情報センター, 学術情報センター, データベース振興センタ。開会に当たっては, ベルリン日独センター, Dr. Graf Brockdorff,
GMD. Professor Dr. Seegmüller, 日本学術情 報センター所長猪瀬博博士，ベルリン市科学技 術担当参事官，前欧州議会議員 Drs Peus など の挨拶があった。また会議終了後その模様が新 聞などに報道された。まず地元べルリンでは日 刊紙 Tagesspiegl 紙 1989 年 10 月 24，25 日付。 日本では朝日新聞 1989 年 11 月 22 日付。 
（1-2) 会議のプレプリントはつぎの通りで，下記の 出版社から入手できる。2nd International Conference on Japanese Information in Science, Technology and Commerce, October 23 25, 1989, Preprint, pp593, Berlin. Post-Conferene Edition (ISBN 90-5199-022-7), will be published by IOS, Van Diemenstraat 94, $1013 \mathrm{CN}$ Amsterdam, The Netherlands.

(2-1) Cecil H. Uyehara, U.S. "Responses" to Japanese science and technology "challenge" - A case study, Preprint.

(2-2) Martha Caldwell Harris, United States -Japan science and technology exchange: Experiences in program development, Preprint.

(2-3) Kaori Niida and Alan Egel, The hightech mission to Japan as integrated information. Preprint.

(2-4) Ichiko T. Morita, The current status of science and technology grey literature in Japan, Springfield, VA., NTIS, June 1988.

$(2-5)$ G. Jacques Sassoon and Shirley V. King, Satisfying needs for Japanese information. Preprint.

(2-6) Database Promotion Center, Database in Japan, 1989, p.54 seq., Tokyo, 1989.

(3-1) Michio Obara, Efforts for internationalization of scientific and technological information in Japan. Preprint.

(3-2) 第 5 セッションでの小原の発表

(3-3) Masamitsu Negishi, Research activities in Japan and Japanese articles registered in Western Database. Preprint.

(3-4) Yuiko Teramura, National Diet Library in recent years. Acquisitions, bibliographies and user services, Preprint.

(3-5) Hideo Setoya, Trends in Japanese database industry. Preprint.

(3-6) Makiko Miwa, Globalization of Japanese database services ; Possibilities and limitations, Preprint.

(3-7) Yoshinao Fukushima and Hal Morimoto, A case study of online business database service in Japan. Application of the service for international communities and unsolved issues, Preprint.

(4-1) Maureen H. Donovan, Reference tools on Japanese science, technology and commerce, Preprint. これらの総合目録は以下の通 $\eta$ 。

Mihoko Miki comp., Union List of Current Japanese Serials in Six East Asian Libraries in Western North America, 1988.

Yasuko Makino comp., Union List of Current Japanese Language Journals in East Asian Collections in the Midwest, 1987.

Union List of Current Japanese Periodicals in the East Asian Libraries of Columbia, Harvard, Princeton and Yale Universities, 1985.

(4-2) Rainer Krempien, Providing access to Japanese scientific periodicals. A survey of the role of German libraries and some considerations on cooperation in Europe, Preprint.

(4-3) Wolfgang Hadamitzky, JAIL Media, A bibliographic information system on Japan, Preprint.

(5-1) Brian Confort, Japanese patent-A major source of technical information and how to access them. Preprint.

(5-2) Eduard Rasek, Some practical considerations on the patent situation in Japan. Preprint.

(5-3) 第 7 セッションでのEduard Rasekの発表

(5-4) Folke Bové, The present state of image database in Japan. Preprint.

(6-1) Mary Jane Ruhl and Ted W. Allen, Assessment of current trends among United States organizations in obtaining Japanoriginated informations. Preprint. 
(6-2) T. Miyakawa, "Information Protectionism" or "Globalism"? - Japanese policy framework since Warwick to Berlin, Preprint. なおこの NTIS Acquitition programを 担当された足立知已氏は 1988 年 2 月, 食道癌の ため死去された。現在の成果は同氏のご努力に 負うところ大である。特に記して故人に謝意を 捧げたい（宮川）。

(6-3) David B Shonyo et al., Japanese technical information resource utilization by U.S. private firms: The Japanese connection, Preprint.

(6-4) Justin L. Bloom, Supply/demand relationships for Japanese technical information in $R \& D$ on advanced ceramics in the United States. Preprint.

(6-5) Mary Jane Ruhl, 前掲

(7-1) Ralph Quinn, The role of the Japanese information consultant in a large international corporation, Preprint.

(7-2) Giuliana A. Lavendel, Footbridge across the gap: Approaching the Japanese information problem, Preprint.

(7-3) Shonyo 前掲

(8-1) Roger Creatrex, Japanese machine translation in the 1990's: The European user's perspective, Preprint.

(8-2) Tsuyoshi Toriumi, Development of machine translation system in JICST. Preprint.

(8-3) Kimio Hosono, Takashi Harada, Tomonori Gotoh, Masayuki Morohashi, Shigeki Umeda, Analyzig characteristics of kanji and katakana scripts of technical terms in science and technology fields. Preprint.

(8-4) Emiko Suzuki, Eiichiro Sumita, Disambignation in Japanese syntactic analysis. Preprint.

(9-1) Lavendel, 前掲

(9-2) Jon Sigurdson and Patricia Nelson, Intelligence gathering on or by Japan: The elusive role of grey literature, Preprint.

(9-3) Shonyo, 前揭

(9-4) Eberhard Bayer, Experiences as a research representatives of Siemens in Tokyo. Preprint.

(9-5) Mary Jane Ruhl 前掲

(9-6) Yukio Nakamura, What is really needed in Japan information-Document or information?, Preprint. 


\section{資料 ペーパーの抄録と討論の要約}

(抄録・要約作成者：宮川隆泰／三輪眞木子／小原満穂）

この抄録は，実際に会議で報告されたペーパーに基づいて作成された。したがって Conference Preprintの abstractとは必ずしも一致しない。

\section{セッション 1。開会 (Opening)}

司会 : Dr. Thilo Graf Brockdorff (Japanisch-

Deutsches Zentrum Berlin, F.R.Germany)

\section{挨拶 (1) Dr. Graf Brockdorff \\ (2) Prof. Dr. Gerhard Seegmüller (GMD) \\ (3) Dr. Hiroshi Inose（学術情報センター） \\ (4) Prof. Dr. Barbara Riedmüller (Senator for Science and Research, City of Berlin) (代読)}

\section{招待講演}

The Japanese press and its relationship toward the modernization of Japanese society

(日本の新聞と日本社会近代化との関連)

Dr. Karl F. Zahl (F. R. Germany)

報告者はかつて広報官として東京のドイツ大使館に 駐在していた。日本の明治維新後の発展には, 日本の 伝統と西欧のインパクトが大きな役割を果たしたが, 日本の新聞の発展にもこのことがよく示されている。 日本の人口は米国の半分であるのに，日刊新聞の発行 部数は米国のそれと肩を並べ，専門家によれば，全体 として質はより高い。

この新聞の発展を日本近代化の鏡として，明治，大 正，昭和戦前，昭和戦後の日本における伝統と西欧の モデルの受け入れとの対立と争い，その上で展開され た継続的・漸進的な日本社会の変容を跡づけた。とく に 1970 年代以降における国民の中産階級化とマスメ ディアの役割に注目している。

\section{セッション 2. 動向と政策 I (Trends \& Pol-} icies I )

司会：中村幸雄（情報科学技術協会, 会長)

\section{Historical development of the Japanese word Joho} （日本語の情報の歴史的変遷）

長山泰介（茨城キリス卜教短期大学）
日本語の情報は現在では英語の informationの意味 を伝える言葉として普通に使われているが，歴史的に はその語義には変遷があった。情報という言葉を日本 語としてはじめて使用したのは森鷗外であり，ドイツ 語の Nachrichtの訳語にあてられていた。こののち情 報は軍事用語として謀報の意味に用いられていた。こ の状態は 1940 年代半ばまでつづいた。

第二次大戦後日本にも米国の情報理論が伝えられ， 科学技術用語として情報という言葉が使用されるよう になった。ここで情報とはUNESCOの用語法に従え ば，デー夕およびその意味の組み合わせにより事実あ るいは概念を伝えるメッセージである。

The European Parliament's considerations on information requirements concerning technological and industrial developments in East Asia （東アジアの技術的・産業的発展に関する情報需要につ いての欧州議会の考察)

Dr. Gabriele Peus (former member of European Parliament)

（ポイス博士のペーパーは配布されなかったので, 以 下は講演要旨の筆記によるものである)

日本の技術は close shopの中にかくされていると 思っていたが, 1987 年 12 月に欧州議会代表として訪 日して，そうでないことがわかった。日本人の，問題 に対する接近の仕方は組織的で，長期計画に基づき長 時間検討するが，一旦決定すると行動は早い。これに 対して欧州人は短絡的で個人主義的である。日本の大 学は産業界との対話が少なかったが，最近は開放政策 をとり始めている。基礎研究では日本のような組織 的・共同的アプローチは，西欧の直観的アプローチに 較べて有効であろうか？

日本には西欧側の watching postを抢きたい。西欧 の直観的アプローチと日本の組織的アプローチの共働 (synergy)が可能である。すでに EC 日本産業協力セン ターがあり，西欧の中級管理者の人材交流，日本語教 
育，日本企業での社内研修を 18 か月間実施している。 西欧にはすでに大量の日本情報が収集されている。 例之ば BL。しかし西欧内情報源の間では調整がとれ ていないし，またPRもされていない。 提案 ; (1)日本の技術開発の意志決定システムについて のコース，データベースについてのコースを作ったら どうか, (2) Pilot Programの結果を広く普及する (EC / Japan Info Projectのことか? )，(3)西欧の大学 において，第五世代コンピュータやロボット工学の研 究を促進する。

\section{Trends in the Japanese database industry} （日本のデータベース産業の動向）

瀬戸屋英雄（通産省機械産業情報局）

日本におけるデータベースサービスの展開を 1970 年代はじめより概観し，主要な政策，組織・団体の発 展を述べた。つぎに日本データベース産業の構造を， 通産省のデータベース台帳総覧のデータを基にのべ, 特に日本ではプロデューサとディストリビュー夕兼業 の事業者・機関の多いことが特徵であるとしている。

国内におけるデータベースの流通と利用も年々増大 しており，1987 年現在では 1,795 の内外の商用デー夕 ベースが利用できるようになっている。このうち 76.3 \%は外国製のもので, 国産データベースは $23.7 \%$ \%で る。ただし利用金額では $65 \%$ が国産 DB 利用額になっ ている。データベースの分野別にみると全体件数の 49 \%がビジネス分野で，科学技術が $28 \%$ ，一般が $20 \%$ の順になっている。

最後に日本データベース業界が当面している問題点 が列挙された。すなわち構築・維持にコストがかかる， 市場でのリスクが大きい, 各種の標準化が不十分, 人 材不足, データベースの価值に対する認識不足などで ある。しかしデータべースサービス振興に対する国内 環境は次第に整備されつつある。1989 年 9 月には我が 国初の全国的データベース展, データベース 89 Tokyo が開催され 28,000 人の来場者を迎えて大成功 であった。

Globalization of Japanese database services;possibilities and limitations

(日本データベースサービスの地球化, 可能性と限界) 三輪眞木子 (エポック・リサーチ, 日 本データベース協会国際委員長)

日本データベースサービスの対外提供状況を，日本
データベース協会調査（1989 年 7 月）により説明。海 外からアクセスできる日本製データベース数は，1987 年の 28,1988 年の 83,1989 年の 104 と年乃増加して いる。しかしこれに伴い以下の問題も指摘されている。 (1)海外でのサービス悹口・代理店設定が容易でない, (2)データベース構築と英文化のコス卜高，(3)国際電信 サービスのコスト高, (4) 日本情報の海外市場の不安定, (5)海外ユーザのニーズが不明確。

海外ユーザのニーズ調查を 1987 年のウォーリック 会議で実施したが，現在のアクセス手段としてデー夕 ベースを使用しているのは全体の $57 \%$ \%でった。将来 使いたい回答者は $87 \%$ 。原報供給は BL 他現地情報源 への依存が高い。日本情報にたいする満足度は, 日本 語読解力のある回答者はきわめて高いが, 読解力のな い場合には半数が不満を持っている。英訳情報に問題 が多いことがわかる。

海外からの日本情報に封するアクセス改善のために は，日本側と海外側の双方向からの努力が必要である。 言語障壁の克服は海外側の問題であるが，日本側は提 供方法の改善, 市場ニーズ把握, 現地サービス空口強 化，PR，日本情報に関するレファレンス機能確立など が求められている。付表あり。1989 年 7 月現在, 海外 よりアクセスできる日本製データベース一覧（日本デ 一タベース協会調查)。

"Information protectionism" or "Globalism" ? Japanese policy framework since Warwick to Berlin.

（“情報保護主義”か “地球主義”か？ウオーリックか らベルリンまでの日本の政策の枠組み)

宮川隆泰（三菱総合研究所）

ウオーリック会議後 1987, 88 年にかけてとられた日 本における情報関連の政策の進展について簡単に触れ ている。GATTウルグアイラウンドにおける TRIP 交渉, 新らしい日米科学技術研究開発協力協定など多 国間および二国間のとりきめや合意についてのべ，つ いで国内政策関連事項を概観。また政府・民間の日本 情報へのアクセス改善に関し, 灰色文献, 学位論文, 特許などにつき各機関・企業の努力をのべた。さらに EC / Japan Info プロジェクト，米国 NTISおよび JTLA の日本技術文献収集計画にたいする日本側の 協力状況につき説明した。最後に今後の課題に触れ, 欧米における日本情報のエンドユーザの具体的なニー ズと，日本の情報源を結びつけるための橋渡しをする 
情報専門家の役割が重要なことを強調した。

討 論

$\mathrm{Q}$ ：基礎研究は個人主義的・直観的アプローチだけで 遂行できるか?

$\mathrm{Q}$ ：日本のデータベース・サービスは 24 時間サービス を提供しないのか?

セッション 3. 動向と政策II (Trends \& Policies II)

司会: David B. Shonyo

(Director, Office of International Affairs, NTIS, USA)

U.S. "Response" to Japanese science and technology "challenges"

（日本の科学技術の挑戦に対する米国の対応）

Cecil H. Uyehara (Uyehara International Associates, USA)

科学技術分野における日本の米国への挑戦を米国側 は真剣に受け止めるべきであるという認識のもとに， 米国では広範囲にわたる対応策が実行に移されてき た。残念なことに，個々の活動が互いに十分調整され ているとは言えず，また，成果が適切な人に十分に伝 えられているとは言えない状況である。確かに, 七ミ ナー, シンポジウム, 立法, 報告, 実態調査, 技術評 価といった面で幅広い活動が展開されてはいるが, 各々はかなり地味な (目立たない) ものである。「日本 技術文献法」自体も，ある意味では議会で強引に作ら れたものであり，新たな資金は与えられておらず，議 会自体の関心も十分とはいえない。

米国の科学技術分野の人材に日本語情報を扱うため の語学教育をする目的で，ニューヨーク大，MIT，， 一スカロライナ州立大, ウィスコンシン大マディソン 校, カリフォルニア大サンディエゴ大が日本語教育プ ログラムを始めている。また, NSF は科学技術分野の 日本との人材交流を実施しており，1988 年には日本で 6 か月以上の研究活動をする人を支援する“Japan Initiative”を開始し, 30 人以上の米国人研究者が日本で 研究活動を行った。

日本の科学技術情報のマーケティング活動について は，料金が高すぎることもあって，成功しているとは 言えない状況である。ジョージ・メーソン大のJapanese Technical Information Research Service や UMI は
サービスを中止しており，米国の科学者・技術者の日 本情報ニーズには安定した基礎ができていない。

半導体産業協会と米国電子産業協会は 1986 年以来 共同で東京に人材を派遣している。米国科学院も 1988 年に日本事務所を開設している。

Updates on U.S. Government activities to acquire and distribute Japanese technical information （日本の技術情報収集における米国政府の最新の活動） Paul T. Feinstein (Japanese Technical Literature Program, U.S. Department of Commerce, USA)

米国商務省の日本技術文献プログラム（Japanese Technical Literature Program) は，1987 会計年度に は 30 万ドル，1988，89，90 会計年度には各 42 万 5 千 ドルを予算として計上しており，これまでに次のよう な活動を実施してきた。(1)議会への活動報告, (2)日本 の科学技術情報の米国内での配布, (3)日本技術文献プ ログラムの活動についての年次報告書の出版, (4)米国 内の日本情報サービスについての年次ディレクトリー の出版, (5) NTIS が日本から入手した文献のレビュ 一, (6) NACSIS (学術情報センター) のシステムおよ びSTN インターナショナルの日本情報サービスの支 援，(7)日英翻訳者コンソーシアムの組織化など。また， 1989 年 12 月 7 日にはワシントン D.C.で機械翻訳の会 議を開催し，1990 年はじめには機械翻訳の調査団を日 本に派遣する予定。

Supply / demand relationship for Japanese technical information in research and development on advanced ceramics in the United States

(米国の先端セラミックス開発における日本の技術情 報の需要と供給)

Justin Bloom (Technology International Inc., USA)

1988 年はじめに, 米国内で先端セラミックスの研究 開発にかかわっている大・中・小企業および大学と国 の研究機関に対して, 日本の技術情報の大手と利用に 関する実態調査を行った。比較をするために, 併行し て米国先端セラミックス協会 (USACA) の会員に対し ても，同様な調査を実施した。両調査ともかなり高率 の回答を得た。

結果は, 大企業および国の研究機関では日本情報を 入手するための公式のプログラムを持っているものが 
$50 \%$ 以上であるのに対し, 中小企業, 大学および非営 利民間研究機関では $20 \% に$ 満たないことが明らかと なった。回答者は日本の先端セラミックス分野の研究 開発レベルを米国と同等であるとみなしているにもか かわらず，日本からの情報入手に対する投資額はかな ク少ない。また，日本情報入手のための公式プログラ ムを持たない機関の間では，このプログラムの設置に ついての関心は小さい。回答者からは，日本の技術発 展を積極的に追跡することに対する関心が薄い理由を 説明する以下のような点 (多い順) が挙げられている。 (1)先端セラミックスの研究開発プログラムの規模が小 さすぎる, (2)従来の方式で十分な情報が得られている， (3)プライオリティが低い, (4)プログラムが開始された ばかりで時間と資金に余裕がない, (5)米国の研究開発 を追跡するだけで精一杯，(6)日本の研究開発は大した ことはない，(7)関心がない(付，質問票)。

Technical information exchange: The United States, Japan and the challenge of internationalization

（国際情報交換：米国と日本の国際化への挑戦）

Wayne S. Kiyosaki (Foreign Broadcast Information Service, USA)

米国と日本の二国間では，非常にあいまいなコンセ プトをもつ「国際化」という問題が, 人々の論議の的 となっている。両国にとって, 国際化への挑戦とは, 米日関係の基盤を抽象化してとらえるのではない。そ れは現実の進展の複雑な経過の中に, 各国の独特の国 家特性を注意深くみつめ実際的に考慮することであろ う。過去 3 年間, 新しい政治の時代を迎えて, 米国は 国家の価值観が変わるような外からの挑戦に直面して いる。急激な社会の変化は，いずれ日本にも同様のジ レンマをもたらすであろう。建設的な技術情報プログ ラムと真の協力は，両国の代表者がこのような基本的 な問題を国際化の全プロセスにインパクトを与えるも のとして認識しない限り，実現しないだろう。

例えば，日本人駐在員は外国に子供を連れて行って も, 結局日本に子供を連れ帰って日本の大学に大学さ せる。これでは, 日本人の国際化はあり得ない。

\section{討 論}

Q：Justin Bloom 氏のペーパーの中では, 大企業にお ける人的な情報交換が含まれていなかったが，こ の点はどうなのか?
A：必要があれば日本に人を送ると回答しており，人 的交流が重要だという認識はある。

$\mathrm{Q}$ ：灰色文献の収集についての研究はどうなったの か?

A：現在なお継続中である。

セッション 4. 動向と政策III (Trends \& Policies III)

司会, G. Jacques Sassoon(British Library Japan Information Service)

\section{What is really needed in Japan information- Documentation or information?}

（日本情報への本当の要求は何か? 文献それとも情 報？）

中村幸雄（情報科学技術協会）

日本情報への需要は本当にあるのか。仮説を四つた てた。第 1 は日本情報への需要は全くない。日本情報 に対する叫び声が上ったとしても，それは別の理由に よるものである。第 2 は需要はまだ顕在化していない というものである。第 3 は需要は確かに存在している が，日本から送り出される情報は適当でなく西欧の市 場に入っていくためには西欧人の手で加工されねばな らない。第 4 は，需要はすでに重要なユーザの間では 充足されている，という仮説である。

この仮説を念頭において，本当に必要とされている のは文献なのか，情報なのかを見極めなければならな い。報告者は第 3 仮説を選び対策を立てたいと述べて いる。つぎに情報は素材のままでなく，解釈を加えた 上で提供される必要があり，そのとき日本についての 知識が重要である。日本情報という材料を欧米人が消 化し易いよう調理してやる必要がある。例えば寿司は アメリカではアメリカ人のロに合うように米風化され ている。腕のいい西洋人の料理人の出現を期待する。

\section{A View from the International House of Japan （国際文化会館の見解）}

東ケ崎民代（国際文化会館）

国際文化会館が設立された 1952 年当時は文化とい う名称は独特だったが,いまでは sensitiveな言葉にな った。その図書室は外国人の日本人研究者のためのク リアリングハウスの役目を果たしてきた。日本人研究 者の出版する本や論文数はいまや莫大な数であるが, 
その中でいわゆる灰色文献の割合は多いし，また科学 技術における情報収集のパターンも日本独自のものが ある。このパターンには, 文献によるもの, 組織内部 の人的コミュニケーションによるもの, および外部の 研究とのコンタクトによるものの 3 種があるが, とく に人的コンタクト，とりわけ異なる領域の専門家のコ ミュニケーションが大事である。国際文化会館はその 面で役に立ちたい。

Accessing Japanese information in science \& technology - Myth vs reality

（日本科学技術情報へのアクセス一神話対現実）

Dr. Bruce Rubinger (Global Competitiveness Corporation. , USA)

報告者は 1982 年以来民間コンサルタントとして日 本の技術発展を分析してきた。現在地球的規模での多 面的技術戦略が展開されており，その中で日本からの 技術の入手も選択の一つである。日本技術へのアクセ スコストは高い。しかし日本の発展に対する無知のコ ストはこれをはるかに上回るであろう。ところが現実 にはUMIの JTIS プログラムが中止に追い込まれた ように，日本情報への関心が米国企業や研究機関の間 でなかなか高まらない。これには米側自身に制度的障 壁がある。日本の先端技術の発見が，米企業研究者の 組織そのものの基礎を摇がしてしまうおそれがあるこ と，日本情報プログラムに彼等の R\&D 予算から資金 を振り向けるのは好まないことなどである。日本科学 技術情報のアクセスへの非難も，確かにアクセスは難 しいのだが，本当は別の所に原因があることもある。 連邦政府は R\&D 予算中より，もっと多くを戦略技術 分析に向けるべきであり，また商務省日本技術文献局 を強化すべきである。

\section{Assessment of current trends among United States organizations in obtaining Japan-originat- ed information \\ （米国機関の日本発情報入手の最近動向の評価） \\ Mary Jane Ruhl and Ted W. Allen (Ruhl Information Management, Inc, USA)}

ウオーリック会議後米国で日本情報サービスが 3 件 中止されている。日本情報に対するニーズは本当にあ るのか。報告書はワシントン DC 地区の日本情報専門 家 17 人と, 情報仲介業者 8 企業を対象にヒアリングと
郵送調査を行った。まず失敗例（UMIの JTIS，ジョ ージ・メースン大学の JTIRS, 米国電子工業会の二ュ ーズレター）と成功例（NTISの Acquisition Program, NSF の JTECH）などを分析。専門家インタビ ユーでは, 日本情報の需要は過去 2 年間ほとんど増加 していないといわれている。彼等は一様に米国機関が もっと日本情報の収集に熱意を示すべきだと指摘。一 方情報仲介業者は営利行為として日本情報サービスを 実施しているが，そのうち 2 企業は過去 2 年間に需要 は $30 \%$ 増大していると述べている。8 社のうち日本の 情報源に $100 \%$ 頼っているのが 3 社, 日米の情報源半 半が 3 社となっている。今後の課題, 米国側の日本情 報の重要性に対する関心の欠如, 潜在的ユーザの教育 (大規模で教育的な振興キャンペーンが必要), 米連邦 政府の役割, さらに日本産業情報の利用パターンの理 解などが強調されている (付, 質問票)。

\section{セッション 5. 情報源 I （Information Sources I ) \\ 司会：Dr. Giuliana A. Lavendel \\ (Manager, Information Resources \\ Palo Alto Research Center \\ Xerox Corporation, USA)}

Research activities in Japan and Japanese articles registered in Western databases

(日本における研究活動と欧米のデータベースに登録 された日本人論文)

根岸正光（学術情報センター）

INSPEC, CA Search, EMBASE, COMPENDEX の 4 大データベースに収録されている論文を計量的に 調査することによって, 24 分野における日本の貢献度 を推定しようと試みた。CA Search 以外の三つのデー 夕ベースでは, 日本人の論文数が過去 10 年間にわたっ て増加し続けているものの，収録対象が欧米人の論文 に偏重している傾向がある。多くの分野において，日 本は米国に次いで第二の地位を占めている。

さらに詳細な分析を加えることにより, 産業界, 大 学および政府機関の 3 セクターの論文数の比率を算出 することを通して, 日本と米国の科学活動の違いを明 らかにした。日本の研究者および学会の活動へ, 言語 障壁と灰色文献の問題も指摘している。これらの問題 は外国のデータベースプロデューサが日本文献の収録 率を増加させようとする際に直面する困難である。 
日本の文献に対する海外からのアクセスを改善しょ うとするNACSISのプロジェクトについても, 学会発 表データベース, 学術雑誌の全文データベースの対外 提供を含めて紹介された。

An outline of the structure of research in Japan and related documentation systems

（日本の研究および関連ドキュメンテーション・システ ムの組織)

Hélène Haon (Cellule Japon, INIST-STM, France)

日本における公的研究機関の構造とそれに関連した ドキュメンテーション機関を紹介。科学技術庁につい てはJICST との関係が, 通商産業省については特許 庁，日本産業技術協会(JITA)，JETRO，日本規格協 会およびデータベース振興センターの活動が，文部省 については学術情報センターの活動が, 農林水産省に ついてはその下にある研究所と情報センターの活動 が, 厚生省については, その下にある研究所と統計情 報部の活動が, 運輸省, 建設省, 郵政省, 労働省につ いても, 各々の役割りと情報提供組織が紹介された。 基本的な認識として, 日本の省庁の縦割り組織の構造 を前提としての情報収集活動の必要性が指摘された。

Efforts for internationalization of scientific and technological information in Japan （日本科学技術情報の国際化への努力）

$$
\text { 小原満穂 (JICST) }
$$

日本で生産された科学技術情報に対する諸外国から の入手要求に答えて, 日本政府, 日本人研究者, 日本 の学会および情報サービス機関は相互に協力し合い, 以下のような努力を進めている。(1)日本政府は科学技 術情報の国際間での流通の不均衡を是正する努力を進 めており, 科学技術情報の様式の標準化を図っている。 (2)研究者は, 国内外の雑誌により多くの論文を英文で 投稿することによって, 国際的な情報伝達の促進を図 つている。(3)学会は, 英文誌の数を増やす努力を進め ると共に，日本語雑誌中の論文に英語の標題や抄録を 付加している。(4) JICST および他の情報サービス機関 では, 日本で生産された科学技術情報を諸外国に提供 するために，英文のデータベースを作成している。英 文データベースの強化および灰色文献の流通のための JICSTの将来計画も紹介。
The Present state of image database in Japan （日本の画像データベースの現状）

Folke Bové（東海大学）

日本では多くの画像デー夕ベースが開発されてお り, 従来のデータベースで得られる情報のほかに, 表 や図や写真も得られるようになっている。これらの画 像データベースは, 日本語のわからない研究者にも有 益であり，言語の障壁を軽減するための道具としても 利用できる。日本の主な画像データベースの内容，フ アイリングと検索の手法, 主題分野別の画像データべ 一スの種類を紹介している。対象とされた画像デー夕 ベースサービスは，日本経済新聞社の NEEDS-IS，工 レクトロニック・ライブラリーの ELNET，毎日新聞 社の MAIHIT, Japan Photo Research Center (日本 写真研究センター）の Photo Disc Library System, 日本特許機構の CD-ROM 版特許データベース, 建設 情報センターの ARCHI-FILE。画像データベースに は，(1)視覚的に魅力あるアウトプット，(2)ファイリン グ手法が簡単, (3)サイズがコンパクト，(4)従来型のデ 一タベースでは収録できない情報を収容できる，とい う利点があるため, 日本では今後重要な役割りを果た すであろう。画像データベースの今後の発展には，フ アクシミリ画像, CD-ROM, 検索手法の改善, 高品位 テレビ等による画像および出力の品質の向上が大きな 影響を及ぼすであろう。

\section{討 論}

$\mathrm{Q} ： 1900$ 年以前の写真が手に入らないか？

A：画像データベースでは無理だろうが, 日本の新聞 社には古い写真を保存しているところもある。

Q：NACSIS-IRの化学全文データベースでの著作権 の処理はどうなっているのか?

$\mathrm{A}$ ：著作権は著者ではなく学会が所有しており, 学術 情報センターと学会の間で了解を得た上で開発し ている。

セッション 6. 情報源 II (Information Sources II)

$$
\text { 司会：宮川隆泰（三菱総合研究所） }
$$

National Diet Library in recent years : Acquisitions, bibliographies and user services

（最近の国立国会図書館：収書, 書誌および利用者サー ビス) 
寺村由比子（国立国会図書館）

日本で唯一の国立図書館である国立国会図書館は， 法で定められたデポジットシステムを通じて日本の出 版物を包括的に収集すると共に，国内外の利用者にこ れを提供している。国立国会図書館の収書の中には, 官公庁出版物，博士論文，会議論文や会議録といった かなり多くの灰色文献も含まれている。国立国会図書 館では日本全国書誌を Japan-MARC データベースと して構築すると共に, 他の書誌も作成している。Japan -MARC データベースは，MT と CD-ROM で外部に も提供している。利用者サービスについては，毎日平 均 1,500 人の来館者に対して閲覧室を提供しているほ か, 年間約 58 万件 (うち約 4 千件は外国から) の郵送 等による複写サービスを実施している。また，公共図 書館拉よび大学図書館に対して資料の貸出しを行って おり，IFLAの図書資料国際利用プログラムを通じて 海外の図書館にも貸出しを行っている。参考調査につ いては，年平均 18 万件の問い合わせを処理しており， うち 65,000 件は電話, 21,000 件は手紙である。海外の 機関および個人からの問い合わせにも対応している。

将来，1996 年に関西地域に第二国立図書館を開設す る計画が進んでいる。この図書館は，国立国会図書館 が作成したデータベースを用いて，日本の書誌情報セ ンターとして複写や貸出しを行う予定である。

Providing access to Japanese scientific periodicals. A survey of the role of German libraries and some considerations on cooperation in Europe （日本の科学技術逐次刊行物へのアクセスの提供— ドイツ図書館の役割りの概観とヨーロッパ内での協力 の可能性)

Dr. Rainer Krempien (Staatsbibliothek Preussischer Kulturbesitz, F. R. Germany)

日本の文献情報を提供しているドイツの図書館シス テムは集中型ではなく，規模や機能の異なる七つ以上 の図書館が，ドイツの図書館相互貸借システムを通じ て，資料の収集やアクセスの提供に協力し合っている 分散型のものである。ごれまでのところうまく機能し てきたこのシステムが，ドイツ国内での日本情報への 迅速なアクセスへの要求の増大に対処できるかどうか は疑問である。ヨーロッパ内の日本文献を所蔵してい る他の図書館との協力を通じて, 現存するコレクショ ンをより有効に活用することが望まれる。この協力と
は，日本の逐次刊行物のヨーロッパ内での総合目録の 作成等である。ヨーロッパ書誌データベースの中に日 本語の文字を組み込めるか, より優れた書誌調整を実 現できるかどうかの問題も生じてくる。

現在のところ，ドイツの図書館において，日本の文

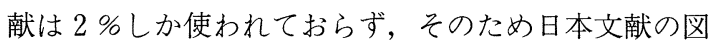
書館におけるプライオリティは低い。これを改善する には，日本語力のある訓練されたカタロガーが不可欠 であるが，ドイツの図書館には日本語と図書館学の両 方を習得している人は少ないため, 人材が不足してい る。

Infotex Japan-A bibliographic Information System on Japan

(Infotex Japan —日本に関する書誌情報システム) Wolfgang Hadamitzky (Staatsbibliothek Preussischer Kulturbesitz, F. R. Germany)

Infotex Japan（別名 JAIL Media）の目的は，日本 に関するあらゆる種類のドイツ語文献の書誌データべ 一スを構築することである。その中には, (1) 15 世紀か ら今日までのあらゆる出版物を含み, (2)単行書, 記念 論文集，会議録，逐次刊行物，および手紙や地図を含 み，(3)日本についての記述が極くわずかであっても， 1850 年頃までに出版されたものを対象とし, (4)記述内 容が異なる同一出版物の異版, 本や逐次刊行物のリプ リント, マイクロ版, 視聴覚資料, CD-ROM および他 の形態の出版物を含み, 全部で約 55,000 冊の文献が収 録されている。これまでのところ，1920 年までに出版 された単行書と雑誌と地図の編纂が完了した。この部 分の書誌情報のほかに，ヨーロッパ，北米，および日 本の主要図書館における所蔵情報も加えられている。 このデータは, ベルリンの日独センターのデータベー スを通じて利用できるようになるだろう。また， 1990 年には印刷体の 6 巻より成る書誌が出版される予定。

A case study of online business database service in Japan. Application of the service for international communities and unresolved issues

（日本におけるオンラインビジネス・データベース・サ 一ビスの事例研究——ービスの海外提供と解決すべ き課題)

福島芳直（平和情報センター）

Hal Morimoto (Comline News Service) 
日本で提供されているビジネスデータベース・サー ビスの数は急激に増加しており，このことはオンライ ンデータベースが日本の日々のビジネス活動において 重要な役割りを果たしていることを示している。この 分野においては, 日本では, リアル夕イム情報サービ スとしてのニュースデータベースが重要である。典型 的なリアルタイム情報サービスでは, 金融, 証券, 為 替情報が提供されており，二ュースデータベースは過 去の市場動向や業界・技術の傾向分析や企業活動につ いての情報を入手する際に最もよく用いられている。

HINET とCOMLINEを通じて提供されている日 本語と英語のオンラインデータベース・サービスの動 向と, 1988 年から開始された外国へのサービスを紹 介。各データベースの収録情報の詳細, 端末および通 信ネットワークの接続条件，コマンドの構造とデータ 検索の手法，およびデータベースの利用料金も提示。

\section{Japanese science and technology information on STN}

（STN 上の日本の科学技術情報）

Ingrid Siegmund-Rux (Fachinformationszentrum Karlsruhe, F. R. Germany)

科学技術情報のネットワークであるSTNInternational は, 科学技術分野の 84 種の書誌情報, ファク トおよびリフェラル情報のデータベースを提供してお り，その中には特許情報も含まれている。書誌データ ベースは, 世界中の研究論文を含んでおう，その中に は多数の日本における研究成果がある。したがって, このデータベースは日本の情報についての素晴しい情 報源となっている。JICST から提供されている JICST -Eファイルは, 中でも最も貴重な情報源である。STN は日本の逐次刊行物および単行書約 250 万点の書誌情 報を提供している。FIZ Karlsruhe は FIZのデータべ ースだけでなく JOIS サービスについても，情報ブロ 一カとしてのサービスを提供している。

\section{Introduction of FIZ Karlsruhe} (FIZ Karlsruhe の紹介)

Dr. Roger Kolb

DEQUIP (化学技術情報のデータベース), DETEQ (特定企業の環境技術情報のデータベース), BIOQUIP (バイオテク)ロジー用の機器を製造している企業情 報のデータベース), MSONLINE (マススペクトラの
データベース), POLYMAT (高分子材料のデータベ 一ス）を紹介

\section{討 論}

Q：STNの JICST-Eファイルでは, JOIS の日本語 のデータベースに収録されている文献のうち何パ 一セントをカバーしているのか？

A : JOISの日本語データベースの中には日本以外の 国で出版された外国語文献も含まれている。

JICST-Eでは，JOISの日本語データベースのう ち日本で出版された文献だけを収録しており, 1985 年以降のすべての論文が含まれている。

$\mathrm{Q}$ ：外国から国立国会図書館に来るレファレンスの問 い合わせは英語で来るのか？それを日本語に訳し て処理をしているのか? もし外国から日本語で問 い合わせをすれば現在より速く回答を得られるの か? 他の図書館（例えば英国図書館）にまわすこ とはないのか?

A：外国からの問い合わせは英語で入ってくるので, それを各専門に振り分けて処理している。各専門 では日本語で回答を作り，それを国際協力課で英 訳してから提供するので，時間がかかっている。 他の図書館に頼むことはめったにない。

\section{セッション 7. 情報源 III （Information Sources III)}

司会 : Hélène Haon

(Cellule Japon, CNRS-INIST, France)

Japanese patents-A major source of technical information and how to access them

（日本特許一主要技術情報源とそれへのアクセス手段）

Brian Comfort (Derwent Publications Ltd., UK)

日本の革新的な技術が含まれる日本の特許情報は， 1988 年においては 30 万件以上出願され, この数は米 国特許の 3 倍，ヨーロッパの 5 倍にも達している。さ らに実用新案を加えると 50 万件以上にもなる。

このような高い数には，日本の工業が健全であると いう他に，研究投資の成果を守るために請求範囲を分 割して出願するという要因も存在する。

Derwent は日本特許に積極的に英文抄録を付与し， Derwent データベースに収録しており，その数は 4,800 件/週で, 対象分野により抄録の長さを変えて いるのが特徵である。この英文抄録を作成するために 
約 100 人の抄録者が訓練されていると共に, 約 60 人の 技術ス夕ッフがチェックを行っている。

Derwent データベースは全世界の特許を対象とし 800 万件以上の記事を持ち，同じ発明が以前になされ ているかどうかを知ることが可能である。またDerwent は冊子体, マイクロフィルム, オンラインサービ スにて英文抄録付き特許情報をサービスしている。今 後は,グラフィックとフルテキストが課題となろう。

Using a translation tool to get online Japanese patent information

(オンラインによる日本特許情報を得るための翻訳ツ ールの利用)

Roland Herberger (Siemens AG, FRG)

日本語の知識なくして, 日本特許のデータベース PATOLIS を検索するために, INPADOCが作成した パソコン用の日英変換ソフトウェアパッケージ “KANJI”エミュレータが発売された。

PATOLIS データベースには日本特許, 実用新案, 商標について出願から登録までの各情報が収録されて いる。この“KANJI”エミュレータを使用することに より，特許等の日本語で表記されている各項目を自動 的に変換することができる。変換方式は，まず検索式 をつくり，それを送信し，検索結果が蓄積され，検索 が終了した後日本語から英語に変換し，オフラインプ リントされる。PATOLIS 以外のデータベースの検索 も可能であるが, 通信速度等でいくつかの問題がある。

Some practical consideration on the patent situation in Japan

（日本における特許状況についての実務的考察）

Dr. Eduard Rasek (BASF AG, FRG)

日本の特許システムの特徵としては以下のことが挙 げられる。

・特許と実用新案が明確に区別されている。

・番号システムが複雑

特許と実用新案, 公開と公告, 昭和と平成それ

ぞれに番号を付与

・西暦年ではなく日本暦年を使用

日本特許にアクセスする手段としてはPAJ (Patent Abstracts of Japan：JAPIO が作成する英文公開特 許情報), WPI, INPADOC, PATOLIS があるが, 最 も包括的にヨーロッパからアクセスできる日本特許情
報としては，INPADOCが代理店となっている PATOLIS データベースである。PATOLIS は 1902 年 まで遡及でき, 3,300 万件のレコードを持ち,オンライ ンで図も検索できる。

1987 年の IPC G 11 B を検索すると以下の結果と なり, PATOLISが最も多い。
- WPI
9,368 件
- PAJ (JAPIO)
15,154 件
- PATOLIS
24,848 件

Reconstruction, signal enhancement and storage of sound material in Japan

（日本における音声の再構成，信号改善おょび蓄積）

Dr.Tjeerd De Graaf

(Univ. of Groningen, The Netherlands)

近年，多くの研究機関は古い音声収納体から音声を 再生すること，逆に音声をデータベース化して収録す ることに興味を示している。

古い音声はワックスシリンダに録音されているが, これを破壊しないで音声を再生することは非常に困難 である。そこで北海道大学・応用電気研究所では, 非 接触のレーザビームの反射と屈折を利用して音を再生 する研究を進めている。この方法は, アイヌ人の話し・ 歌の再生に応用され，非常に有用なデータが言語学者 や人類学者にとって利用可能となる。

また，音響データの蓄積のために，コンパクトディ スクやDATレコーダといった最近の光学・ディジ夕 ル技術を利用する。この方式は，通常の音声収納体に 比していくつかの有利な点をもつ。

さらに，日本では文部省補助によるいくつかの音響 データベース作成のプロジェクトが進められており， 185 人の大学の研究者が参加。音響データベースは, ATR で開発が進められている自動通訳電話システム にも応用ができる。

Intelligence gathering on or by Japan: The elusive role of grey literature

（日本の,あるいは日本による情報収集：灰色文献のつ かみどころのない役割)

Prof. Jon Sigurdson (Uuiv. of Lund, Sweden)

日本企業における研究開発の戦略部分ともいえる在 色情報あるいは灰色詳報 (grey intelligence) に関し て，事例を用いつつ，灰色文献を含むより広い概念の 
灰色情報および灰色詳報の演じる重要性について考察 した。

灰色情報あるいは死色詳報は全情報の $10 \%$ 程度を

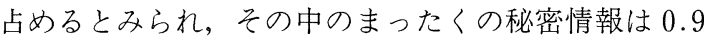
\%程度とみられる。

灰色詳報は，口頭あるいは書類として生じるもので， 公開情報に比較して，入手が困難かあるいは入手に長 時間必要とされる情報であるとし，とりわけ人間どう しの直接的コンタクトが日本の組織では重要とされ る。

また，エレクトロニクス産業の中でも IC 製造技術 に関連した超真空技術の開発プロセスでの灰色詳報の 例を取り上げている。

科学技術庁がスポンサーである科学技術振興調整費 による超真空技術のプロジェクトは多くの研究機関， 大学，民間企業の 9 機関によって推進され，当初予定 の成果が得られたが，以下の点が特筆される。

一あまり著名ではない民間企業が高い技術力を有

し，重要あるいは中核的な役割を担った。

- 9 機関間の研究者の広い人的ネットワークが形成 された。

セッション 8. 分析と流通 (Analysis \& Distribution)

司会：Dr. Jon Sigurdson (University of Lund, Sweden)

Satisfying needs for Japanese information : user needs, problems, wish list and BL-JIS activities （日本情報ニーズを充足する：利用者のニーズ，問題， 今後の希望一覧および英国図書館日本情報サービスの 活動）

Shirley V. King and G. Jacques Sassoon (British Library, U.K.)

英国図書館日本情報サービスでは，質問サービス， セミナー, 出版, 言語支援, 研修などの業務を担当し ている。質問は主に産業界からくる。情報源は BL 館内 の所蔵資料とオンラインデータベースである。所蔵資 料の中に日本情報に関する資料の最小必須セット (minimal set) がある。実際に BL/JIS で利用されて いる資料につき，企業情報，製品情報，統計，学協会 情報政府刊行物など具体的に挙げられている。

BL / JIS は本稿執筆の前月 (1989 年前半のある月) に 91 件の質問を英国内から全部電話で受け付けた。う ち $70 \%$ はロンドン地区からのもので，全体の $46 \%$ が
産業・工学に関するもの，45\%が貿易・商業に関する ものであった。また全体の $55 \%$ \%が特定企業に関する質 問, $14 \%$ が統計数字に関するもの, $10 \%$ が欧州に進出 している日本企業に関するものであった。回答に利用 されている日本製データベースは，日経テレコムと TSR である。質問は同日中に $90 \%, 8$ 日以内に $100 \%$ 回答されている。最後に解決を希望する 11 項目が挙げ られている。

Footbridge across the gap: Approaching Japanese information problem

（ギャップを埋める歩道橋；日本情報問題へのアプロ 一チ)

Giuliana A. Lavendel (Xerox Corporation, USA)

最近日本製データベースや速報サービスなどが増え ているが，これらは高価で遅い。利用者は満足してい ない。日本からの情報は文化, 言語, 遠隔地にあるこ とのため流通の方式が米国情報とは異なっている。情 報は簡潔で, cost-effective で, タイムリーでなくては ならない。アメリカの企業や機関は日本情報をつかま えてこれにフィル夕をかけるシステムを確立しなけれ ばならない。

このため「歩道橋方式 (footbridge solution)」を提 案する。これは文化と情報収集・利用方式のちがう日 本情報資源と米国ユーザとの間を橋渡しするものであ る。学協会, 出版物, 灰色文献などについて, 米国内 の日本情報関係者, 日本国内の直接コンタクト先など を使うことなどが内容となっている。

Biotechnology Abstract Analyser I and II : An attempt for the cotinuous assessment of leaders in a High-Tech field with special reference to Asian countries

（バイオ技術抄録分析 I・II，ある先端技術分野におけ る指導者の継続的評価の試み，とくにアジア諸国との 関連において)

Sabine Triebel and Rolf D. Schmid. (Gesell -schaft für Biotechnologische Forschung,

F.R.Germany）（U.Wattenberg 代読）

バイオセンサ，蛋白質に工学および animal tissue cultureの分野における日本, 韓国, 中国の研究に関し, 著者名々所属研究機関, 協力研究機関につき, Chemical Abstract (CA) と Current Contents (CC) を検索 
してデータを収集し，研究所別，分野別に分類し，デ ータベースを形成した。

Reference tools on Japanese science, technology and commerce.

（日本の科学技術および商業に関する参考書誌類）

Maurreen H. Donovan (The Ohio State University Libraries, USA)

日本に関する参考書誌類は，迅速なアクセスが要求 されるハイテク情報が脚光を浴びている現在，時代遅 れで静的な手段とみなされ易いが，その内容，有用性， 所在については十分議論されていない。企業内図書館 で，人物や企業の名前やアドレス，その他の便覧類あ るいは統計類へのアクセスが難しいと言われている が，多くの資料はすでに日本で出版されており，その 上米国内に所蔵されている。ここではつぎのような参 考書誌が具体的に取り上げられている。情報源ガイド， 便覧，年鑑と統計，政府刊行物ガイド，企業情報，社 史, 事典・辞書など。重要な資料は日本語で日本で刊 行されている。これに関する知識をもてば日本の情報 世界の仕組みを知ることができる。

全米の日本情報源（とくに大学図書館）が所蔵する 文献については調整と協力が必要であり，このため日 米友好委員会 (Japan-U.S.Friendship Commission) の資金援助を得て，東海岸，中西部および西海岸の大 学図書館日本コレクションのコンソーシアムができて おり, 所蔵逐次刊行物のユニオンリストが作成されて いる。日本参考書誌類の活用とそれに関するレファレ ンスによる支援は，日本情報の利用促進のため重要な 役割を果たすであろう（含，主要参考書誌りスト）。

The role of the Japanese information consultant in a large international corporation （大手国際企業での日本情報コンサルタントの役割） Ralph M. Quinn (AT \& T, Bell Laboratories, USA)

大企業内部の日本情報のユーザは, 研究者, 技術者, 経営者とそれぞれ異なるニーズがあり，提供すべき情 報の種類・形態・頻度・媒体も異なっている。これら は企業内で異なる市場を形成している。大企業情報部 内の日本情報コンサルタントの役割は, 必要な日本情 報を外部から購入し，これを最良の商品に仕立てて社 内のユーザに売ることである。エンド・ユーザのニー ズは個性的である。日本情報コンサルタントは, 社内
に各種形態の日本関連情報を提供しているが，その中 には，速報，ニューズレター， journal contents bulletins, 定型的情報提供, レファレンスサービス, 翻訳サ 一ビス，一次資料提供などがある。

大企業内日本情報コンサルタントの役割は，企業内 に'one stop shopping'サービスを提供することであ ク，これを社内情報ネットワークに載せて流すことで ある。今後このような大企業情報部内の日本情報専門 家の役割はきわめて大事なものとなるであろう。

\section{討 論}

$\mathrm{Q}$ ：(BL/JIS のサービスにたいし), 回答はどのように するか,また料金はとるのか？

$\mathrm{A}$ ：電話やファクシミリで回答している。オンライン 検索，複写，ファクシミリ送信などには課金して いる。

$\mathrm{Q}$ ：(ATTの日本情報サービス), ユーザの回答要求の Uん度はどのくらいか。

A：アンケートをとったことあり。毎日 $51 \%$, 毎週 27 $\%$, 週 2 回 $3 \%$, 無回答 $19 \%$ 。

\section{セッション 9. 言語と漢字処理}

\section{(Language \& Kanji Processing)}

司会：長尾真

(京都大学工学部電気工学科, 教授)

Japanese machine translation in the 1990s: the European user's perspective

(1990 年代の日本の機械翻訳システム : ヨーロッパ利 用者の展望)

Dr. Roger Greatrex (Univ. of Lund, Sweden)

多くの日英あるいは英日機械翻訳システムが存在し ているが，ヨーロッパの利用者は利用時期，能力，今 後の進展等についてジレンマをもっている。しかし， 箱根さらには大磯において開催された国際会議におい ては,メーカ, 研究機関の機械翻訳部門が強化されて いることが発表され，また大手メーカ等がワークステ ーション上で動く機械翻訳システムのデモンストレー ションを行った。例之ば，日立，日本電気，東芝，三 菱電機, 沖電気, リコー, 三洋電機の各ワークステー ション用機械翻訳システムがある。しかし,これらは, システムとハードウェアが結びついており，これがヨ 一ロッパの利用では問題になりそうである。ブラビス のシステムのみがどのメーカのパソコンでも動く。 
今後の課題としては, (1)翻訳の対象あるいは分野を 制限, (2)辞書の拡充, (3)ソフトウェアの開発, がある。

\section{討 論}

$\mathrm{Q}$ ：機械翻訳におけるデータベースとのインタフェイ スはどうとっているのか？

A：パソコンにダウンロードした後，これをセレクト

し,プレエデットおよびポストエデットしている。 $\mathrm{Q}$ ：人間による翻訳と比較して機械翻訳のコストは?

A：情報専門家が利用すると $30 \sim 35 \%$ 低下する。

Analyzing characteristic of kanji and katakana scripts of technical terms in science and technology field

(科学技術分野での技術用語に関する漢字, カタカナ表 記の特性分析）

\author{
細野公男（慶應義塾大学，教授） \\ 原田隆史（慶應義塾大学） \\ 後藤智範 (愛知淑徳大学, 教授) \\ 諸橋正幸，梅田茂樹(IBM 東京基礎研)
}

日本語は漢字, カタカナ, Uらがなという異種類の 文字によって表記される。しかし表記の標準がないた め, 自動索引・分類, オンライン情報検索, 自動翻訳 といった日本語情報の効果・効率的処理を妨げている のが実情である。

科学技術分野における技術用語も漢字, カタカ十あ るいはこれらの組み合わせで形成されている。技術用 語を構成する漢字は用語の基礎的な構文情報を与える という面で重要であり, 一方カタカ十は独自な概念の 外国語を音訳する場合，あるいは漢字ないしはUらが なで表現することが適切でない場合に用いられる。

ここでは, 二つの分析を行った。第 1 は漢字の特定 分野での出現頻度の分析により, 自動情報分類方法を 開発すること，第 2 はもとの外国語から音訳された力 十の多様性を検討すること。このため JICST ファイル の電気工学編の抄録をコンピュー夕処理し, 以下の結 果を得た。

○ある漢字の 12 分野における出現頻度を見た場合, 相互に密接な関係を有する。

○情報に含まれる重要な漢字を利用することによ り，情報の分類が可能となる。

○カナによる外国語の音訳は多様であり，これらが 日本語処理を困難にしている。
Development of a machine translation system in JICST

(JICST における機械翻訳システムの開発)

鳥海剛 (JICST)

JICST で開発している実用規模の機械翻訳システ ムの開発の経緯, 目的, システム概要, スケジュール, 開発状況，将来計画について記述している。

JICST のシステムは 1982 年から 1985 年の 4 年間 に科学技術振興調整費により行われた「日英科学技術 文献の速報システムに関する研究」の成果を利用して いる。このプロジェクトは科学技術情報の国際的流通 のニーズに答えて，英文抄録を効率的に作成すること を目的として, 科学技術庁, 京都大学, 電子総合研究 所, 工業技術院, JICST の協力で行われ，良好な結果 を得た。

本システムは 1989 年度から試験的に JICST-E フ アイルの抄録作成利用に用い，その性能を評価する計 画である。その後, 1990 年度から本格運用に入る。こ のシステムは現在 3,000の文法規則を持つと共に, 翻 訳辞書は 30 万語に達している。今後の課題は, システ 厶改良, 日本語の問題, 運用体制, OCR 入力である。

Some Application of an Integrated Computer System Abroad Equipped with Japanese Characters

（日本文字を搭載した海外の統合コンピュータシステ 么の利用)

\author{
Dr. Kennosuke Ezawa \\ Prof. Tetsuya Ishikawa \\ Frank-Dieter Bechter \\ (Universität Tübingen, FRG)
}

日本語処理機能を持つコンピュータが海外では少な いことから, 日独辞書プロジェクトでは, 日本のコン ピュータ科学者および企業と共同で，日本語で利用可 能な統合コンピュータシステムを完成させた。機器構 成はホストに DECの VAX, 端末に DECの PC, NEC の PC 98 シリーズ数台を持ち, 記憶装置として SONY の CD-ROM を持つ。

これらの機器はPLANET と呼ばれる LAN と接続 され JOISへのアクセスも可能である。さらに PLANET BITNET に接続したので日本での辞書 プロジェクトの研究者と直接コンタクトできる。

この統合システムを利用し, 日本語あるいは独語の 
いずれかを知っている学生のための検索システムを開 発した。この検索システムは会話型教育支援システム であり，操作が容易で多くの支援機能を持っている。

また，このシステムは通常の辞書システムとは異な り，語句が抽出された多くの例文を所有していること から，例えば日本語を入力した場合，その文章に対応 する多くの独語の文章表現を知ることができる。

\section{討 論}

$\mathrm{Q}$ ：辞書の拡充は考えているのか？

A：日本語の標準化がまず必要と思う。

\section{Disambiguation in Japanese syntactic analysis （日本語の構文解析におけるあいまい性の除去）}

鈴木恵美子，隅田英一郎 (IBM 東京基礎研)

構文解析は自然語データベース検索・回答，機械翻 訳のような自然語処理分野で重要な要素である。

ここでは日本語解析装置を設計し実験した。この文 章解析装置は形態素解析装置と構文解析装置とから構 成され，構文解析は水谷文法を基礎として，自由文脈 文法（Context-Free Grammer）をあいまいさの解釈 用として用いた。

文章解析装置を用いて試験を行った結果，採用した 方式は短い文章に対しては成功したが，長い文章や実 際の文章にはあいまいさが多く見られた。

これを解決するため, 構文解析に推計学の手法を用 い，多くのデータからあいまいさを生じさせる言句を 抽出・分析後，実際の文章を正しく修正する解析の規 則をつくった。試験の結果, 推計学の手法は高い精度 を示した。

\section{討 論}

$\mathrm{Q}$ ：このシステムの精度と将来計画は？

A：あいまいさについては $75 \%$ の精度を達成してい るが新聞記事のみである。将来は科学技術分野も 行いたいが，文章が長く単語も長いのが問題。シ ステムはパソコンで動くが多くの制限がある。

\section{セッション 10. 直接の接触 (The Direct Con- nection)}

司会：Justin L. Bloom (Technology International, Inc. USA)
Japanese technical information resource utilization by US private firms: The Japan connection （米国民間企業による日本技術情報源の利用）

David B. Shonyo, A. Rahman and Janet H. Geffner (USDC/NTIS, USA)

このペーパーは，日本科学技術情報源が米国民間企 業にとってどの程度利用可能であるかを見極めるため に実施中の調查の一部分である。日本科学技術情報に 対しては，日本の技術的進歩にきわめて高い関心があ るにもかかわらず，科学技術情報そのものに対しては 需要は少ないという逆説的現象がみられる。日本語は 障壁になっているが情報ニーズはあり，翻訳文献の中 にはNTISのべスト七ラーに入っているものもある。

大企業の多くは日本に直接の足場をもっており，日 本科学技術情報収集については，とくに困難はない。 Westing house, AT \& T, Dow Chemical, TRW, Lockwell などの事例が紹介されている。これらの企 業は日本社会の中にそれぞれの活動を織り込んでい る。NTISの調査によると大企業は R\&D プロジェク トの成果報告書のような詳細な技術情報を要求する が，一方小企業はレピュー型のニューズレターや技術 専門誌を要求して扬り，需要は二極分化しているよう に考えられる。

The high-tech mission to Japan as integrated information（総合化された情報としてのハイテク調 査団の日本への派遣)

Kaori Niida and Alan Engel (International Science an Technology Associates, USA)

ISTA は 1987 年に設立され，日本の新技術開発事業団 の代理業務を米国で担当している。現在米側機関との 契約の下に, NSF の JTECH プログラム (日本技術評 価）に基き日本の ERATO（創造科学技術推進事業） を評価するために，米国から調査団を日本に送りこむ 業務を支援している。日本の研究所への調查団の団体 派遣そのものが総合化された情報であり，その中では 人間的ネットワーク，政府や産業団体に関する知識, 日本の習慣，旅行業務知識などが，データベースや一 次資料と同様に重要な意味を持っている。最近実施し た JTECH 派遣団に関して直面した困難は，第 1 が文 化の違い，第 2 が有効なコンタクト先の開拓，第 3 は 旅行業務の実際，第 4 が日本語の順であった。日本側 
に信頼されること，有効なネットワークを維持するこ とが大切である。

\section{Opportunities for foreign researchers in Japan : ERATO}

(外国人研究者の日本における機会：創造科学技術推 進事業)

Dr. Alan Engel (International Science and Technology Associates, Inc, USA)

新技術開発事業団の創造科学技術推進事業 (ERATO) では 1981 年から外国人研究者を招いて研 究に参加を認めているが, この学際的基礎研究は外国 人研究者には日本の科学技術についての知識を深める のに役立っている。ERATO では現在 17 の研究所で 13 の研究プロジェクトを実施している。1981 年以来 1989 年 3 月までに 27 人の外国人研究者が, 日本企業 もしくは外国企業の補助をうけて参加している。研究 者の出身国は米国の 6 人が最も多いが,他は 15 か国に 分散している。外国人参加者は, 研究の過程で日本人 研究者と肩を並べて最先端の研究をするほか，日本の 研究所・大学の組織, 日本の特許制度に対する知識を 深めている。これらの研究者は帰国後それぞれの組織 内で重要な情報源になっている。

\section{Experiences as a research representative of Siemens in Tokyo}

\section{(シーメンス社研究駐在員としての東京での経験)}

Dr. Eberhard Bayer, (Siemens A.G, F. R. Germany)

西独シーメンス社は 1887 年以来長い間日本に事務 所を置いてきたが, 1983 年はじめてシーメンス本社研 究開発部門が東京に駐在員を常置することとなり，報 告者が初代研究駐在員になった。任務は(1)文献調査, (2)学協会・展示会への出席, (3)シーメンス社と日本の 間の訪問のとりきめ, (4)定期報告。1983 年 1 月から 85 年 9 月迄の 2 年 8 か月間に, 70 人のシーメンス社員を 414 の日本企業・研究所に紹介し, また 125 人の日本人 をシーメンス社に紹介した。

当初季刊で発行されていた社内報「Siemens Japan News」も現在では隔月刊になっている。社内配布部数 は 300 部である。

\section{セッション 11. 最終パネル討論}
司会；
U. Wattenberg, F. R. Germany

パネラー ; G. J. Sassoon, U. K.

J. L. Bloom, USA

東ヶ崎民代旦本

長尾 真旦本

(議事録作成前のため, 宮川・三輪の筆記メモより要約 して作成した)。

パネラーの発言要旨

Bloom：1983 年に米国の MIT で初めて日本情報の会 議を 20 人の米人専門家が集まって開いて以後, 今日ま でのことを振り返ってみると大きな進歩があった。問 題は，解決のための条件になった。政治的文脈は無視 できないが，日本情報への関心は底流で高まっている。 最近民間でも日本科学情報対策が出現, 全米科学・工 学アカデミーで対日方針の検討を開始。また米企業の 日本の $\mathrm{R} \& \mathrm{D}$ 施設への投資が増加している。

一方，日本情報入手のための経費は大（例えば翻訳 代)。民間小企業には負担できない。米政府の欧州に対 する姿勢と日本に対する姿勢では相違があり。米政府 はもっと日本情報政策に力を入れるべきだ。Positive Sum Gameをしたい。

東ヶ崎：在来型情報源に加えて, 画像, オーディオ, 音声などが登場，また全文 DB も増加，これらはよい 方向である。日本情報に関しお互いに何をしているか よくわかった。相互の努力のターゲットを絞りたい。 図書館のような在来型情報源も高い評価をえており, 勇気づけられた。今後の問題一情報の価格づけの問題, 人的資源をどう確保するか。

Sassoon：前回 Warwickのときの目的は需要と供 給のギャップを見つけることだった。日本情報はほし いが費用はかけられないという環境があった。今では 入手可能になったものも多く, 多くの新サービスも現 れた。灰色文献もその一つ。まだ利用者は少ないが, 今後子えると確信している。日本人にサービスを要求 するのは迷惑かと思っていたが，その感覚が最近はな くなった。

長尾：日本情報に関心が高いのに驚いた。機械翻 訳のプログラム開発は終ったが，現状ではすぐ利用で きる状態ではない。アジア周辺国の機械翻訳計画も進 んで扔り通産省が支援している。文部省では外国人向 け日本語教育システムに応用されている。基本的問題 の一つは, 日本人研究者の論文執筆姿勢である。機械 翻訳しやすいような明確な文章を書くよう研究者を教 育する必要がある。自己宣伝や難解な表現はやめよ。 大事なことは文献を読むことでなく，技術移転である。 
文化と日本人の性格を理解することが必要だ。

討 論 :

C. Kay（米）：日本語教育や翻訳者の問題について は今回は論じられなかった。利用者の声もまだ明確に はきけなかった。

E. Rasek（独）：日本の安価な小型 PC はなぜ欧州 では入手できないのか。

三輪：灰色文献が定義されていない。

M. J. Rnhl (米) : 扊色文献をフォーマットからみ るのでなく，ニーズからみるべきだ。セクター主題, 地域などによってニーズがちがい，したがってフォー マットもちがう。

Bove (デンマーク)：人間による翻訳と機械翻訳の 有効性の比較が必要だ。機械翻訳は技術的には意味が あるが，長期的には人間の翻訳者をふやすことを考え るべきだ。

Uyehara（米：仲介者だけでなく利用者の話をき きたかった。同じことを何回も英語で繰返してくれる 日本人の忍耐に感謝したい。米側の責任はもっと沢山 の利用者を次回の会議につれてくることだ。

Lavendel(米)：日本語教育システムの話, 情報の価 格の話をもっとききたい。

A. J. Davies (英)：どんどん入ってくる新しい情報 に驚いている。今後ニュースレターのようなものを出 してはどうか。日本情報関係者だけでなくもっと幅広
い情報サービス関係者に呼びかけては？

Ruokonen(フィンランド)：会議名称のCommerce は適切ではない。Business, Industry と改めよ。またこ の分野の話ももっとあってよいのではないか。

Consigny (EC)：日本大企業が情報システムをどう 組織しているか知りたい。

中村：よく組織された会議で，参考になった。

宮川：知的所有権問題が今後の情報流通に影響を及 ぼすので，論じてほしい。

$\operatorname{Vinard}($ 仏): 大変参考になった。主な情報は公開さ れていることも判った。人的コンタクトによるプライ ベート情報も大事。人的関係をどう組織化するのか。 日本企業ではどうやっているか。企業では文献だけで なく, 数值データの方が重要。

Sigurdson（スウェーデン）：関心のある問題, 機械 翻訳，大企業における技術戦略である。

C. Kay (米)：米国翻訳者協会で日本語部門を作り 200 人登録し, 技術辞典を共有。また日本語から英語へ の翻訳者の資格認定試験も実施している。

Brian Howells (英) : 英国翻訳者協会にも日本語部 あり，他国と協力している。情報源は同じで夕ーゲッ トがちがうだけである。日本の英語翻訳者とのネット ワークと西欧の日本文献翻訳専門家とをつなぐチャネ ルをつくりたい。

Haon（仏）：次回をフランスで開くことにつき関心 あり, 今後検討したい。 